\title{
Modification of Molten Steelmaking Slag for Cement Application
}

\author{
João B. Ferreira Neto ${ }^{1}$ João O. G. Faria ${ }^{1} \cdot$ Catia Fredericci $^{1} \cdot$ Fabiano F. Chotoli $^{2}$ • \\ Andre N. L. Silva ${ }^{1} \cdot$ Bruno B. Ferraro $^{1} \cdot$ Tiago R. Ribeiro $^{1} \cdot$ Antônio Malynowskyj $^{1}$ • \\ Valdecir A. Quarcioni ${ }^{2} \cdot$ Andre A. Lotto $^{1}$
}

Published online: 13 October 2015

(C) The Minerals, Metals \& Materials Society (TMS) 2015

\begin{abstract}
The use of metallurgical slags in cement production depends on the phases present in such slags, which are affected by changes in slag composition as well as the cooling rates adopted during solidification. In this work, slags with distinct chemical compositions were melted and subjected to different cooling conditions. Slag samples were characterized by X-ray diffraction to identify and quantify mineralogical phases and by $\mathrm{X}$-ray fluorescence to determine chemical composition. The microstructure of the samples was characterized by scanning electron microscopy coupled to energy dispersive spectroscopy for phase identification. The solidification of the slags was simulated using FactSage $^{\mathrm{TM}}$ for solidification path evaluation, enabling a comparison of the phases determined by thermodynamic equilibrium with those analysed in slag samples. Slags with low basicity $\left(\mathrm{CaO} / \mathrm{SiO}_{2}<1.25\right)$ and $\mathrm{Al}_{2} \mathrm{O}_{3}$ content of $11 \mathrm{wt} \%$ exhibited a high glassy phase content
\end{abstract}

The contributing editor for this article was Yiannis Pontikes.

João B. Ferreira Neto

jbfn@ipt.br

Catia Fredericci

catiaf@ipt.br

João O. G. Faria

joswaldo@ipt.br

Fabiano F. Chotoli

fchotoli@ipt.br

Andre N. L. Silva

alnunis@ipt.br

Bruno B. Ferraro

brunobf@ipt.br

Tiago R. Ribeiro

tiagorr@ipt.br depending on the cooling conditions. The phases formed in slags with higher basicity (1.4 and 3.8) were less affected by cooling rate and were different silicates, such as larnite, merwinite, monticellite, akermanite, gehlenite and melilite, whereas slags with basicity $\geq 1.37$ exhibited RO phase (solid solution of $\mathrm{FeO}, \mathrm{MgO}, \mathrm{CaO}$ and $\mathrm{MnO}$ ).

Keywords Steel slag $\cdot$ Cement $\cdot$ Slag cooling · Thermodynamic simulation

\section{Introduction}

Brazil has produced approximately 32 millions of tons of crude steel in the last 10 years, and there is no expectation of growth. By contrast, the construction industry has growth more than $5 \%$ per year. This scenario predicts a lack of blast furnace (BF) slag for the cement industry in Brazil in the near future. Steelmaking slag (SS) could be an

Antônio Malynowskyj

antoniomaly@ipt.br

Valdecir A. Quarcioni

quarciva@ipt.br

Andre A. Lotto

andrelotto@ipt.br

1 Laboratory of Metallurgical Processes, Institute for Technological Research (IPT), 532 Av. Prof. Almeida Prado, São Paulo, SP, Brazil

2 Laboratory of Civil Construction Materials, Institute for Technological Research (IPT), 532 Av. Prof. Almeida Prado, São Paulo, SP, Brazil 
alternative in cement mineral admixture, partially as a substitute for BF slag [1-4]. However, the use of SS directly in cement admixture is not allowed due to expansion during hydration, which occurs despite the presence of $\mathrm{Ca}_{2} \mathrm{SiO}_{4}$ $\left(\mathrm{C}_{2} \mathrm{~S}\right)$, which exhibits hydraulic activity, as one of the main mineral phases in this slag. This expansion is caused by the presence of free $\mathrm{CaO}$ and $\mathrm{MgO}$ and $\mathrm{Mg}$-rich wustite ( $\mathrm{RO}$ phase) $[5,6]$. Therefore, the chemical composition of steel slag must be modified to prevent volume soundness and to improve its hydraulic activity to increase its applicability in cement manufacturing. The hydraulic activity of slags is affected by the chemical composition of the main and minor chemical constituents, glass content and their combination [7]. Mostafa et al. [7] reported that highly basic slags $\left(\mathrm{CaO}+\mathrm{MgO} / \mathrm{SiO}_{2}+\mathrm{Al}_{2} \mathrm{O}_{3}=1.5\right)$ are mainly crystalline and that a glassy structure forms in acidic slags containing sufficient $\mathrm{Al}_{2} \mathrm{O}_{3}$, even with slow cooling. By contrast, the development of crystalline or glassy phases and crystal size and purity depend on cooling conditions [8]. Gautier et al. [8] reported that slow cooling of SS enhances the crystallization of $\mathrm{C}_{2} \mathrm{~S}$ and periclase, whereas faster cooling results in $\mathrm{Ca}_{3} \mathrm{SiO}_{5}\left(\mathrm{C}_{3} \mathrm{~S}\right)$ and lime. Here, a pyrometallurgical process to promote the modification of the chemical composition of molten steel slag under distinct cooling rates to make it more appropriate for cement manufacturing was investigated.

\section{Methodology}

\section{Materials}

Table 1 shows the chemical composition of the two slags used in this work, which were supplied by an iron and steelmaking company in Brazil: a BF slag and a basic oxygen furnace (BOF) SS. Table 1 also presents the chemical compositions of modified SSs, SS-M1, SS-M2, SS-M3, SS-M4 and SS-M5, which were produced by adding by-products of the metallurgical and civil construction industries in Brazil. Two by-products were used, one rich in $\mathrm{Al}_{2} \mathrm{O}_{3}$ (BPAl) and one rich in $\mathrm{SiO}_{2}$ (BPSi). Slags SS-M1 and SS-M2 were produced at lab scale, whereas slags SS-M3, SS-M4 and SS-M5 were produced at pilot scale. Table 2 shows the amounts of slags and byproducts (BPSi and BPAl) added to the slags as modifier agents.

\section{Sample Preparation of BF, SS, SS-M1 and SS-M2: Laboratory Scale}

The purpose of these experiments was to study the effect of cooling rate and chemical composition on slag crystallization.

One kilogram of each slag was re-melted and processed in a $15 \mathrm{~kW}$ induction furnace under argon at a temperature range of $1500-1600{ }^{\circ} \mathrm{C}$. The SS slag as well as modified slags (SS-M1 and SS-M2) were re-melted and processed in $\mathrm{MgO}$ crucibles, whereas the BF slag was re-melted in a graphite crucible. After melting, the slags were poured in an experimental apparatus comprising a cylindrical

Table 2 Amount of slag and by product (BPSi and BPAl) added to the salgs (wt\%)

\begin{tabular}{lllll}
\hline Slag and modified slag & BF & SS & BPSi & BPAl \\
\hline BF & $1 \mathrm{~kg}$ & - & - & - \\
SS & - & $1 \mathrm{~kg}$ & - & - \\
SS-M1 & - & $1 \mathrm{~kg}$ & $167 \mathrm{~g}$ & - \\
SS-M2 & - & $1 \mathrm{~kg}$ & $250 \mathrm{~g}$ & 100 \\
SS-M3 & - & $300 \mathrm{~kg}$ & $50 \mathrm{~kg}$ & - \\
SS-M4 & - & $300 \mathrm{~kg}$ & $50 \mathrm{~kg}$ & - \\
SS-M5 & - & $300 \mathrm{~kg}$ & $25 \mathrm{~kg}$ & $25 \mathrm{~kg}$ \\
\hline
\end{tabular}

Table 1 Chemical

compositions and basicity $\left(\% \mathrm{CaO} / \% \mathrm{SiO}_{2}\right)$ of $\mathrm{BF}$ slag and steel slag (SS) supplied by an iron and steelmaking company in Brazil and modified slags SSM1, SS-M2, SS-M3 and SS-M4 (wt $\%)$

\begin{tabular}{|c|c|c|c|c|c|c|c|}
\hline \multirow[t]{2}{*}{ Components (\%) } & \multicolumn{4}{|c|}{ Lab scale (1 kg) } & \multicolumn{3}{|c|}{ Pilot scale $(300 \mathrm{~kg})$} \\
\hline & $\mathrm{BF}$ & SS & SS-M1 & SS-M2 & SS-M3 & SS-M4 & SS-M5 \\
\hline $\mathrm{Fe}_{2} \mathrm{O}_{3}$ & - & 13.6 & 4.4 & 0.6 & 6.0 & 2.0 & 3.1 \\
\hline $\mathrm{FeO}$ & 0.2 & 18.3 & 7.3 & 2.4 & 7.2 & 7.6 & 13.2 \\
\hline $\mathrm{Fe}^{0}$ & - & 0.2 & 0.3 & $<0.1$ & 0.9 & 0.3 & 0.1 \\
\hline $\mathrm{CaO}$ & 41.5 & 38.1 & 38.5 & 33.1 & 37.9 & 37.3 & 34.5 \\
\hline $\mathrm{S}$ & 0.7 & 0.1 & $<0.1$ & 0.1 & 0.1 & $<0.1$ & 0.1 \\
\hline $\mathrm{SiO}_{2}$ & 33.1 & 9.9 & 27.5 & 30.2 & 27.7 & 32.2 & 21.6 \\
\hline $\mathrm{Al}_{2} \mathrm{O}_{3}$ & 10.5 & 1.7 & 2.6 & 11.5 & 2.1 & 4.8 & 10.7 \\
\hline $\mathrm{MgO}$ & 7.2 & 8.6 & 10.6 & 13.2 & 10.8 & 9.8 & 10.4 \\
\hline $\mathrm{TiO}_{2}$ & 0.6 & 0.3 & 0.3 & 0.2 & 0.3 & 0.2 & 0.3 \\
\hline $\mathrm{MnO}$ & 0.6 & 4.4 & 4.5 & 2.1 & 4.4 & 3.1 & 3.8 \\
\hline $\mathrm{P}_{2} \mathrm{O}_{5}$ & 0.0 & 1.3 & 1.5 & 0.4 & 1.2 & 0.8 & 1.1 \\
\hline $\mathrm{CaO} / \mathrm{SiO}_{2}$ & 1.25 & 3.85 & 1.41 & 1.10 & 1.37 & 1.16 & 1.6 \\
\hline
\end{tabular}


(a)

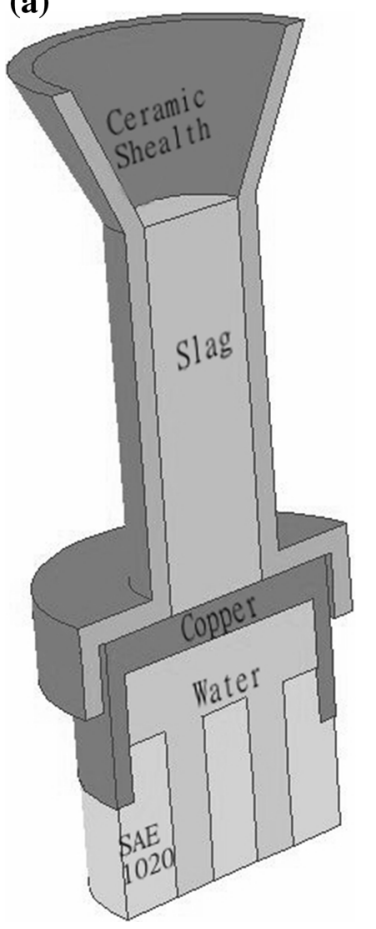

(b)

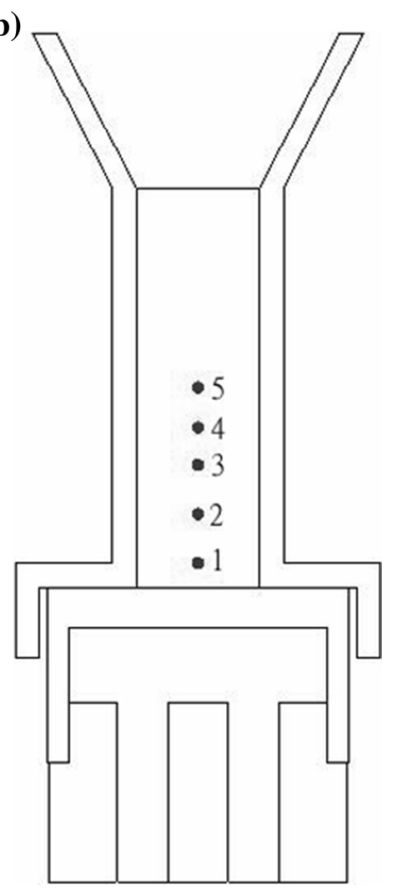

Fig. 1 a Schematic representation of the experimental apparatus constituted by a ceramic mould fixed on top of a water-cooled copper plate and $\mathbf{b}$ thermocouples installed in distinct heights of the mould

ceramic mould fixed on top of a water-cooled copper plate. Thermocouples were installed at distinct heights of the mould, as outlined in Fig. 1, to produce cylindrical slag samples approximately $50 \mathrm{~mm}$ in height and $50 \mathrm{~mm}$ in diameter. Slag cooling curves were used to validate a heat transfer model constructed using COMSOL Multiphysics $^{\mathrm{TM}}$ software. The model adopted a $2 \mathrm{D}$ axisymmetric geometry for the assembly, a mesh element size less than $1 \mathrm{~mm}$ and physical properties of the slag estimated according to Mills et al. [9]. The boundary conditions were the following: (a) heat loss occurs by radiation on the top of the slag and by natural convection on the mould walls; and (b) at the initial time, the temperature of the slag was set between 1500 and $1600{ }^{\circ} \mathrm{C}$, depending on the slag condition. To avoid thermal shock effects in the mould during slag pouring, the mould wall was preheated to $600{ }^{\circ} \mathrm{C}$, whereas the temperature of the copper plate was maintained at room temperature because it was cooled by water. These parameters were adopted in the heat transfer model. The copper plate was constantly cooled by a water flow at a high rate inside the piece. The water was used to maintain the temperature of the plate at low values, which we set initially as room temperature. The contact between the slag and the copper plate was adjusted based on a convection coefficient of $200 \mathrm{~W} / \mathrm{m}^{2}{ }^{\circ} \mathrm{C}$. This coefficient was defined by comparing calculated temperatures and experimental data.

\section{Samples Preparation of SS-M3, SS-M4 and SS-M5: Pilot Scale}

These modified slags were produced in a metallurgical reactor [10] by adding modifying agents to $300 \mathrm{~kg}$ of molten SS slag. Two samples of the same slag (SS-M3) were produced, one naturally cooled in the same reactor in which the modification process occurred (SS-M3a) and one cooled by steel balls (SS-M3b) using the technique developed and patented by the company Paul Wurth, which has authorized the Institute for Technological Research (IPT), based on a cooperation agreement, to perform tests using such cooling conditions. The principle of cooling by steel balls is described in the patent [11] and in the literature [12]. Three samples of slag SS-M4 were obtained, a first one naturally cooled in the metallurgical reactor (SSM4a), a second one cooled by steel balls (SS-M4b) and a third one cooled by water quenching (SS-M4c). The slag SS-M5 was cooled only by steel balls. Figure 2 presents a
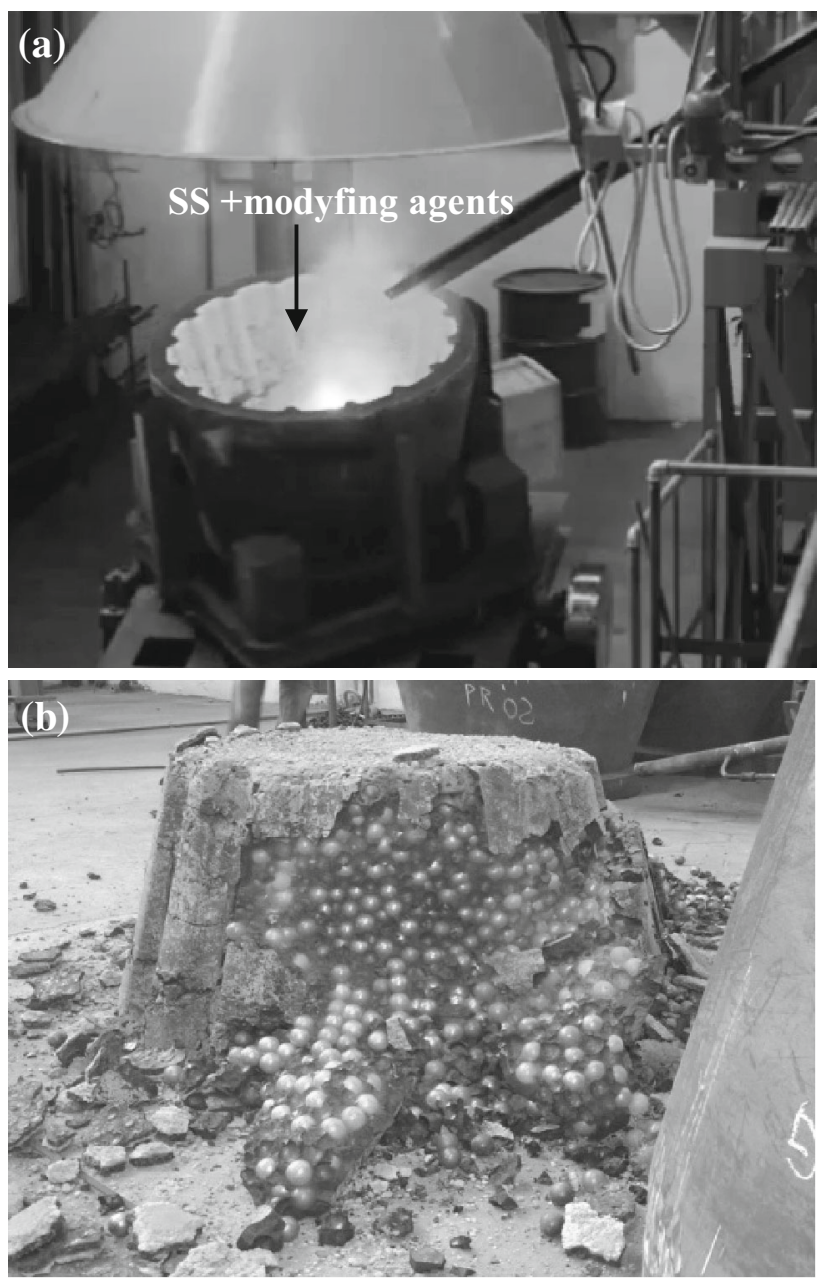

Fig. 2 a SS slag being chemically modified in the pilot reactor and b modified slag quenched by steel balls 
picture of the pilot process for producing SS-M3. The objective of these experiments was to investigate the effect of cooling conditions on the modified slag crystallization.

\section{Characterization of samples of BF Slag (BF), Steel Slag (SS) and Modified Slags}

The cylindrical slag samples of BF, SS, SS-M1 and SS-M2 were sliced using a diamond saw to obtain small samples $30 \mathrm{~mm}$ long and $1.5 \mathrm{~mm}$ wide from the mould bottom. These samples were embedded in resin, polished, and covered with a thin layer of gold for analysis by dispersive energy spectroscopy (EDS, EDAX System) under a scanning electron microscope (FEG Quanta 3D, voltage of $20 \mathrm{kV}$ ). To determine the composition of each different crystal morphology or glassy phases in the samples, EDS analyses were performed on at least five points of each sample. Analyses were performed from the bottom to the top of the sample in steps of $1 \mathrm{~mm}$.

Other slag samples were cut from the rest of the cylindrical slag sample approximately $1-2,5$ and $30 \mathrm{~mm}$ from the interface with cooper cooled plate, resulting in slices approximately $1 \mathrm{~mm}$ thick, which were milled below 325 mesh using a sieve. The produced powders were manually pressed into a $27 \mathrm{~mm}$ diameter sample holder and analysed in a Rigaku Windmax $1000 \mathrm{X}$-Ray powder Diffractometer on a rotating sample stage with $\mathrm{Cu} K \alpha$ radiation ( $40 \mathrm{kV}$ and $20 \mathrm{~mA})$, a step size of $0.02^{\circ} 2 \theta$, time per step of $2 \mathrm{~s}$ and $1^{\circ}$ divergence slit. Mineral identification and phase quantification by the Rietveld method were performed in X-Pert HighScore version 3.0 days (3.0.4) based on standard diffraction data provided by International Center For Diffraction Data (ICDD). ZnO was used as internal standard for the glassy phase measurement.

The rest of the cylindrical slag samples were milled and homogenized for analysis by X-ray fluorescence using a Panalytical Minipal Cement using fused beads produced in a Claisse M4 fusion machine. This equipment was calibrated using commercial standard materials (BS, BAS, CANMET, ECRM, IPT, NHKG, NIST, SLOVAK and CECA). $\mathrm{Fe}^{2+}$ was characterized by dichromate titrimetry (ASTM E 246-10), metallic iron was determined according to the procedure proposed by $\mathrm{Xu}$ et al. [13], and $\mathrm{Fe}^{3+}$ was calculated from the difference among total iron, $\mathrm{Fe}^{2+}$ and metallic iron.

\section{Thermodynamic Simulations}

Thermodynamic simulations were performed using FactSage 6.4 software to predict the phases formed during slag solidification. The simulations were performed using the Equilib tool with the FToxid and FactPS databases. The selected liquid solution was FToxid-SLAGA, and the solid solutions were FToxid-MeO_A presented as RO in the results, FToxid-bC2S and FToxid-aC2S presented as larnite, FT-oxid-Mel presented as melilite and FToxid-OlivA presented as olivine; tricalcium silicate was considered in the calculations. In addition, all pure solid and liquidus were also selected as possible outcomes of the simulation, and the gas phase was not considered. The calculations were based on the chemical compositions presented in Table 1, normalizing to $100 \%$ the amounts of $\mathrm{CaO}, \mathrm{SiO}_{2}$, $\mathrm{MgO}, \mathrm{Al}_{2} \mathrm{O}_{3}, \mathrm{FeO}, \mathrm{Fe}_{2} \mathrm{O}_{3}$ and $\mathrm{MnO}$.

\section{Cement Compositions}

Chemically modified steel slags SS-M4b and SS-M5 were ground in a ball mill to a particle size less than $0.075 \mathrm{~mm}$. Those samples were mixed with Ordinary Portland Cement (OPC) in a proportion of $25 \mathrm{wt} \% / 75 \mathrm{wt} \%$ (modified slag/ Portland cement) to produce Portland Slag Cements (PSC, similar to CEM II/B-S), named PSC-SS-M4 and PSC-SSM5. Slag samples SS-M4 and SS-M5 were selected for cement preparation because SS-M4 exhibited a high glassy phase content, whereas SS-M5 exhibited a high crystalline phase content, including $\beta-\mathrm{C}_{2} \mathrm{~S}$, which exhibits some hydraulic activity. Cements manufactured with $\mathrm{BF}$ slag (PSC-BFS) and SS (PSC-SS) were also prepared using the same ratio $(25 \%$ slag $/ 75 \%$ Portland cement $)$ for comparison.

Compressive strength and volume soundness tests of the PSC and OPC samples using the Le Chatelier method were performed according to Brazilian Standard NBR 11578 (analogous to European Standards EN 197-1, ISO EN 196-1 and ISO EN 196-3). An autoclave expansion test was also performed according to standard ASTM C 151. The reactivities of the PSC and OPC samples were determined by measuring the heat generated during hydration for $72 \mathrm{~h}$. The experiments were performed out using a Thermometric Tam Air isothermal calorimeter at $25{ }^{\circ} \mathrm{C}$. Cement paste with a $0.5 \mathrm{w} / \mathrm{c}$ ratio for each sample was mixed for $3 \mathrm{~min}$ at $1000 \mathrm{rpm}$, resulting in a $15 \mathrm{~g}$ sample that was loaded in a capped flask before heating.

\section{Results and Discussion}

\section{Chemical Composition}

As shown in Table 1, the slag modifying process resulted in partial reduction of iron oxides, an increase in $\mathrm{SiO}_{2}$, and, in some cases, an increase in $\mathrm{Al}_{2} \mathrm{O}_{3}$ content due to the action of modifying agents. The target compositions of the modified SSs were defined in order of decreasing $\mathrm{CaO} /$ $\mathrm{SiO}_{2}$ ratio from 3.8 to approximately 1.25 , which is the typical basicity of BF slags, which exhibit excellent 
performance as cement admixtures. Although the $\mathrm{CaO} /$ $\mathrm{SiO}_{2}$ ratio changed to 1.1 (SS-M2) and 1.6 (SS-M5), the iron oxide content in the modified slags was different from that of the iron oxide in the $\mathrm{BF}$ slag. The analysis revealed the presence of $\mathrm{Fe}_{2} \mathrm{O}_{3}, \mathrm{FeO}, \mathrm{Fe}^{0}, \mathrm{CaO}, \mathrm{S}, \mathrm{SiO}_{2}, \mathrm{Al}_{2} \mathrm{O}_{3}$, $\mathrm{MgO}, \mathrm{TiO}_{2}, \mathrm{MnO}$ and $\mathrm{P}_{2} \mathrm{O}_{5}$.

\section{Mineralogical Composition}

Table 3 presents the mineralogical phases of slag samples determined by X-ray diffraction (XRD) adopting the Rietveld methodology for quantification according to sample slag height, from the mould bottom to a height of approximately $30 \mathrm{~mm}$.

\section{BF Slag}

As shown in Table 3, a high quantity of glassy phase was observed in BF slag (94.6 wt\%) only at $2 \mathrm{~mm}$ from the chilled plate. At $5 \mathrm{~mm}$ from the mould bottom, the amount of glassy phase decreased to $5.3 \mathrm{wt} \%$, and the content of other phases such as merwinite, melilite and akermanite increased. This trend continued, and at $30 \mathrm{~mm}$ from the mould bottom, the amount of glassy phase was negligible; the main phase was melilite (95.7 wt\%), which is typically found in BF slags cooled slowly [14, 15]. Melilite is a solid solution of gehlenite $-2 \mathrm{CaO} \cdot \mathrm{Al}_{2} \mathrm{O}_{3} \cdot \mathrm{SiO}_{2}$ - and akermanite $-2 \mathrm{CaO} . \mathrm{MgO} .2 \mathrm{SiO}_{2}-$ and contains all the main constituents of $\mathrm{BF}$ slag, i.e. $\mathrm{CaO}, \mathrm{SiO}_{2}, \mathrm{MgO}$ and $\mathrm{Al}_{2} \mathrm{O}_{3}$.

Figure 3 shows micrographs obtained by electronic scanning microscopy of BF slag at different heights. Only the glassy phase was observed near the chilled copper plate, as indicated by the number 1 in Fig. 3a. At $5 \mathrm{~mm}$, some crystalline phase (region 2) containing small crystals was present between the glassy phase, forming a dendritic structure. The EDS spectrum of this region included $\mathrm{Mg}$, $\mathrm{Ca}, \mathrm{Si}$ and $\mathrm{O}$, which are presented in phases such as merwinite and akermanite, and $\mathrm{Al}$, which is found in melilite and glassy phase (Table 3). At $30 \mathrm{~mm}$, the entire sample was apparently crystallized. EDS analysis revealed the presence of $\mathrm{Ca}, \mathrm{Si}, \mathrm{Mg}, \mathrm{Al}$ and $\mathrm{O}$ in region 3, which are found in the melilite phase. Based on Rietveld analysis (Table 3), $95.7 \mathrm{wt} \%$ of the crystalline phase of the sample located at $30 \mathrm{~mm}$ from the mould bottom was melilite.

Based on the heat transfer model (Fig. 4) and validated by the experimental cooling curves for BF slag, it was possible to estimate the average cooling rates between 900 and $1400{ }^{\circ} \mathrm{C}$ at 2 and $5 \mathrm{~mm}$ from the chilled plate. The differences between the experimental and calculated curves were related mainly to uncertainties in the physical properties of slags and their variation with temperature, as distinct crystalline phases can precipitate depending on the cooling conditions. These rates were estimated as $3.9^{\circ} \mathrm{C} / \mathrm{s}$ and $2.6^{\circ} \mathrm{C} / \mathrm{s}$, respectively. Therefore, by adopting cooling rates higher than $4{ }^{\circ} \mathrm{C} / \mathrm{s}$, more than $95 \mathrm{wt} \%$ glassy phase was predicted in BF slag. The cooling rates for the glassy/ crystalline transition observed in this paper are much lower than those determined by Kashiwaya et al. [15] but relatively close to the rates determined by Gan et al. [16] in BF slags of 0.5 to $1{ }^{\circ} \mathrm{C} / \mathrm{s}$. Discrepancies are attributable to differences in the chemical compositions of slag samples, which can affect the beginning of crystallization. For example, the alumina content of BF slag adopted by Gan et al. (17.6 wt $\%)$ is much higher than the alumina content of BF slag used in the present work (10.5 wt\%); alumina contributes to the stabilization of the glassy phase in slags [7]. These differences may also be related to the DSC technique adopted by Gan et al. [16] to evaluate slag crystallization, which may not be sufficiently sensitive to detect, via thermal effects, the formation of small crystals during slag cooling.

Figure 5 presents the thermodynamic simulation of $\mathrm{BF}$ slag solidification performed using FactSage ${ }^{\mathrm{TM}}$ software. The solidification of BF slag starts at $1420{ }^{\circ} \mathrm{C}$ and causes the formation of merwinite and melilite. As the temperature continues to drop, the amount of merwinite increases up to $15 \mathrm{wt} \%$ at $1380{ }^{\circ} \mathrm{C}$ and then starts to decrease due to the formation of larnite, $2 \mathrm{CaO} . \mathrm{SiO}_{2}$. The amount of melilite continuously increases up to $82 \mathrm{wt} \%$ at $1310^{\circ} \mathrm{C}$. Further transformations shown in Fig. 5 are less likely to occur due to the absence of a liquid phase and the slow kinetics of solid-state reactions.

The results of the thermodynamic simulations can be compared to those presented in Table 3. In the experimental apparatus, the slag cools at higher rates in regions closer to the copper plate. Thus, the equilibrium solidification path presented in Fig. 5 is interrupted at different temperatures for different heights in the mould. For example, the BF slag sample taken at $2 \mathrm{~mm}$ has $94.6 \mathrm{wt} \%$ glassy phase and $4.6 \mathrm{wt} \%$ merwinite. This composition corresponds well to the distribution of phases at $1410{ }^{\circ} \mathrm{C}$ in Fig. 5. At this temperature, the BF slag $(\sim 95 \mathrm{wt} \%)$ is considered entirely transformed to the glassy phase.

The samples at $5 \mathrm{~mm}$ and $30 \mathrm{~mm}$ have less than $5 \mathrm{wt} \%$ glassy phase, corresponding to approximately $1350{ }^{\circ} \mathrm{C}$ in Fig. 5. At this point, the simulation predicts the end of slag solidification and the presence of $80 \mathrm{wt} \%$ melilite and $15 \mathrm{wt} \%$ dicalcium silicate. The high amount of melilite agrees well with the results in Table 3 as akermanite is simulated in the form of melilite. The absence of dicalcium silicate indicates that the predicted transformation of one into the other did not occur. These differences could be explained to kinetic factors because the simulation results assume equilibrium conditions. 


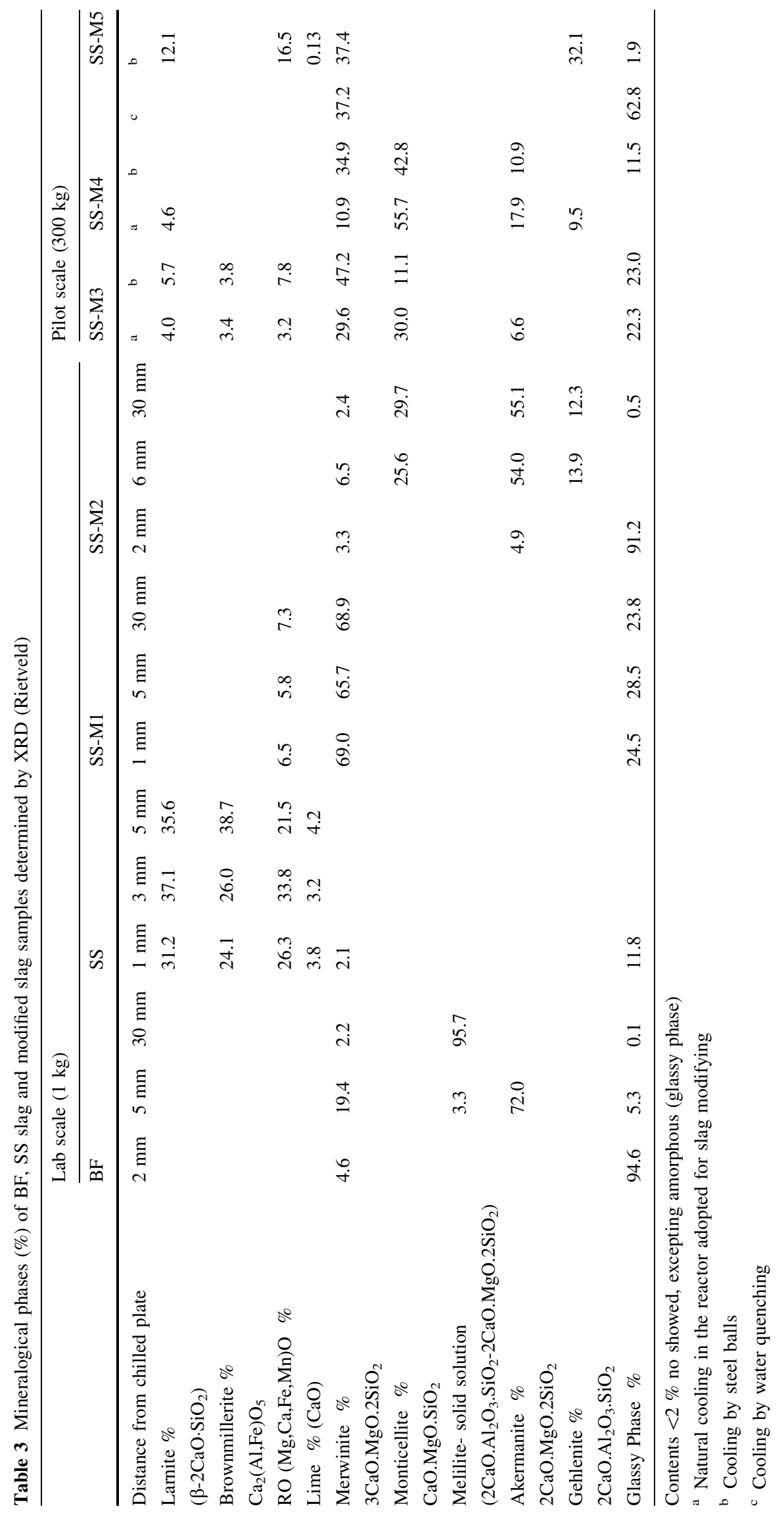


(a)

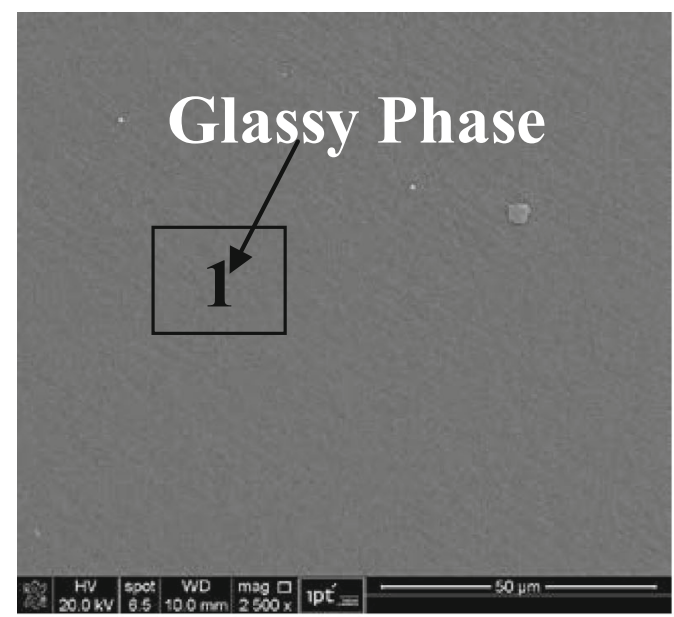

(b)

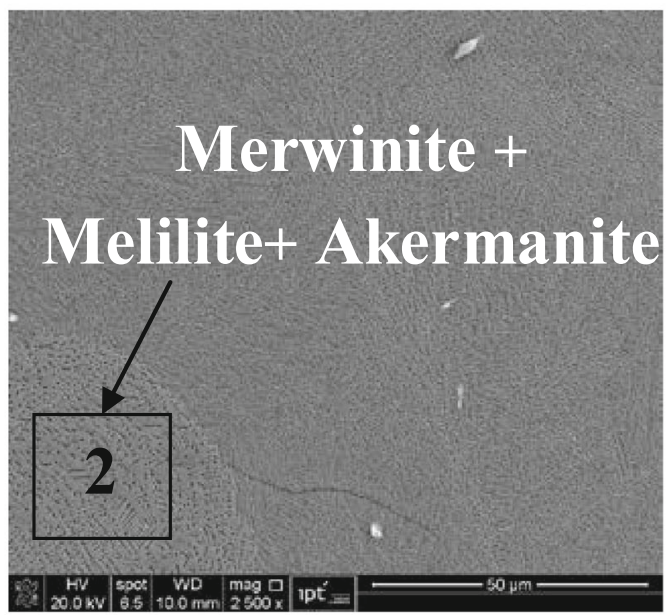

(c)

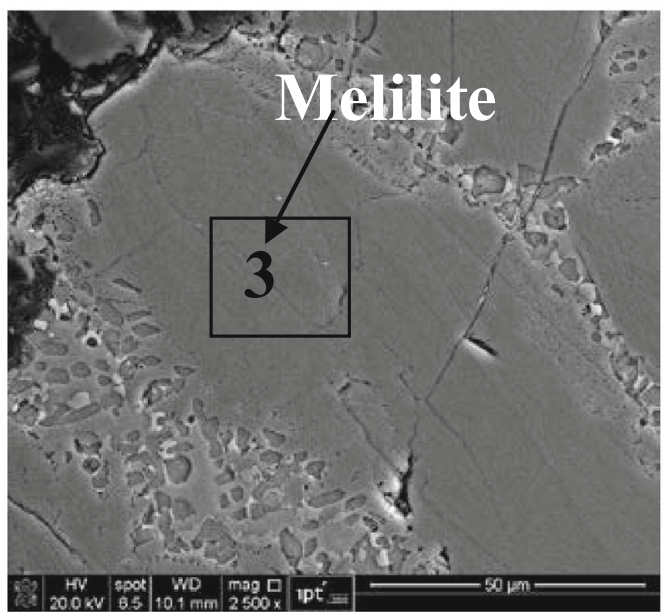

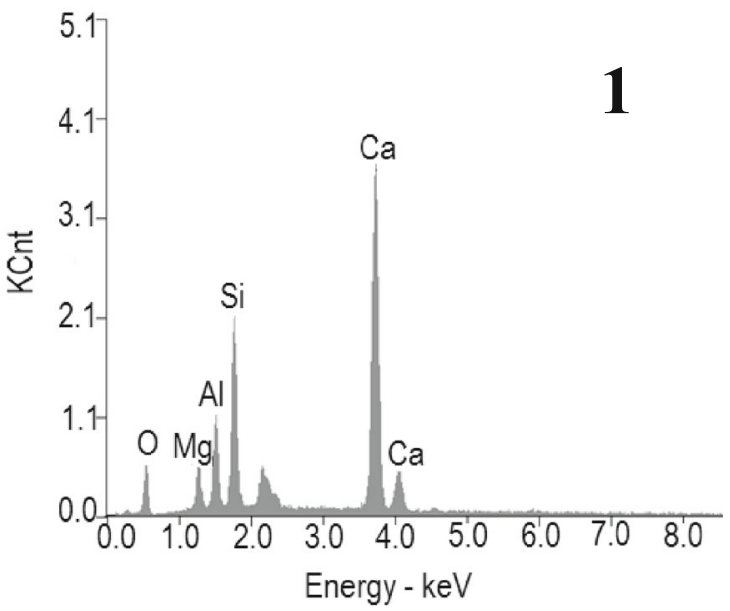
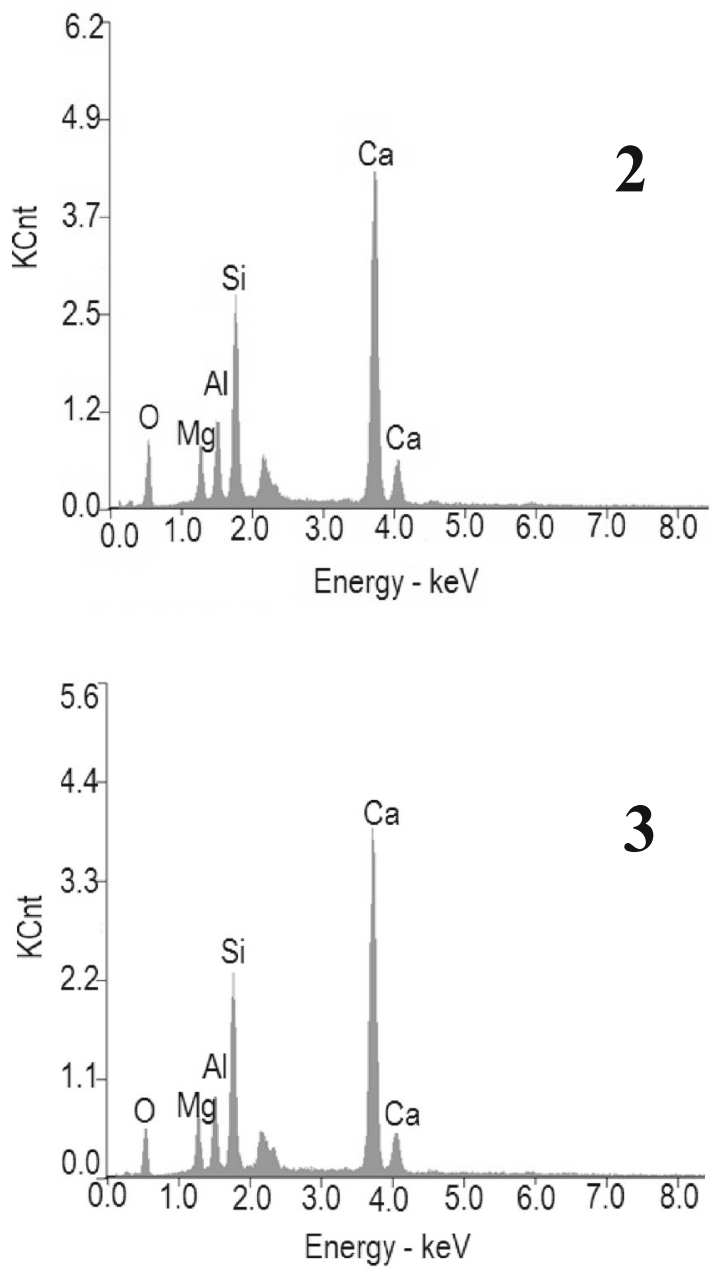

Fig. 3 Micrographs by scanning electron microscopy (secondary electron image): a BF (2 mm), b BF (5 mm) and c BF (about $30 \mathrm{~mm})$ and EDS spectra of points indicated in the figures. The peak at about $2.00 \mathrm{keV}$ corresponds to Au used for samples recovering

\section{SS Slag}

As shown in Table 3, SS is mostly crystalline, even at heights closer to the chilled plate, where only $11.8 \mathrm{wt} \%$ amorphous phase was detected, indicating the difficulty of stabilizing a glassy phase in a SS, even under fast cooling, because this type of slag has high basicity $(\mathrm{CaO} /$ $\left.\mathrm{SiO}_{2}=3.8\right)$ and a high content of iron oxides, which can 
Fig. 4 Cooling curves (experimental $\times$ heat transferring model) for BF slag. TC-experimental cooling curves at 3.5 and $20 \mathrm{~mm}$ from mould bottom (dashed lines). HT Model-simulated curves at $2 ; 3.5 ; 5$ and $20 \mathrm{~mm}$ from mould bottom

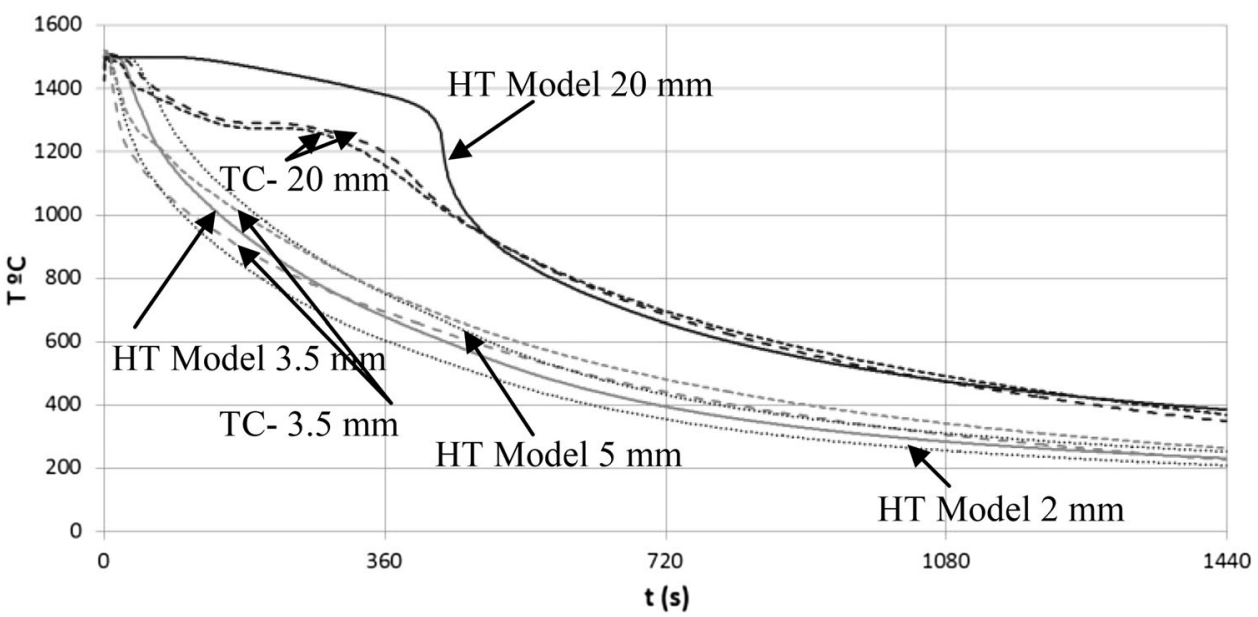

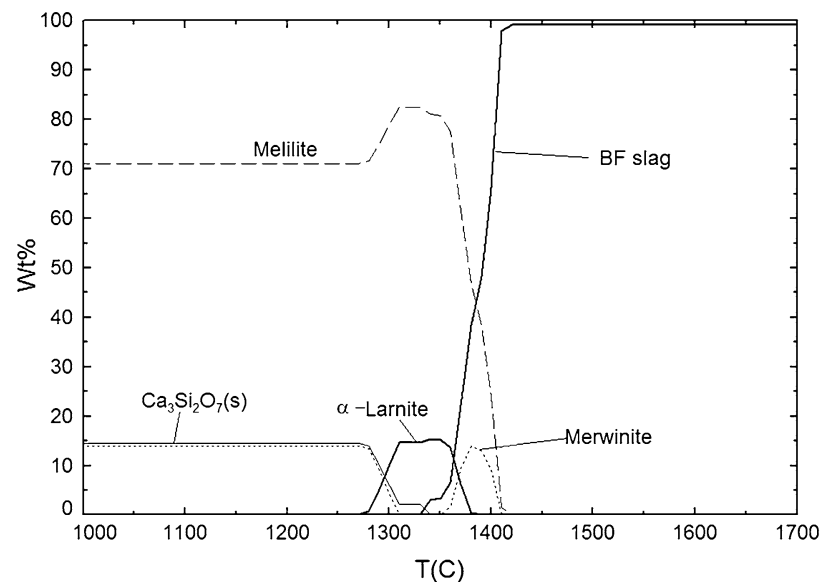

Fig. 5 Thermodynamic simulation of BF slag solidification performed in FactSage ${ }^{\mathrm{TM}}$ software

act as nuclei for crystallization [17]. The crystalline phases are those typically observed in SSs $[4,8,18]$ : brownmillerite $\left(\mathrm{BM} ; \mathrm{Ca}_{2}(\mathrm{Fe}, \mathrm{Al})_{2} \mathrm{O}_{5}\right)$, larnite $\left(\beta-\mathrm{Ca}_{2} \mathrm{SiO}_{4}\right), \mathrm{RO}$ phase (solid solution among $\mathrm{FeO}, \mathrm{MnO}, \mathrm{MgO}$ and $\mathrm{CaO}$ ) and lime. An increase in BM was also observed under slower cooling because calcium ferrite, or calcium ferrite with some iron substituted by aluminium (BM), is one of the last phases to crystallize, as observed by Gautier et al. [8], increasing the likelihood that $\mathrm{Fe}$ will be substituted by other elements, such as Al. The lime content, as determined by XRD (between 3.2 and $4.2 \mathrm{wt} \%$ ), is too high to prevent volume soundness. Interestingly, these phases were predicted by the FactSage ${ }^{\mathrm{TM}}$ simulation during the cooling, as shown in Fig. 6. The liquidus temperature is $1875^{\circ} \mathrm{C}$. The first phase to form is RO, which is initially composed of $\mathrm{MgO}$. As the temperatures decreases, the amount of RO phase increases, and larnite is formed at $1525{ }^{\circ} \mathrm{C}$. Further temperature decreases cause an increase in both larnite and $\mathrm{RO}$ and the formation of lime at $1450{ }^{\circ} \mathrm{C}$ and $\mathrm{BM}$ at $1180{ }^{\circ} \mathrm{C}$. Notably, $\mathrm{C}_{3} \mathrm{~S}$ was not detected by either XRD or thermodynamic simulations due to the precipitation of $\mathrm{CaO}$ and $\mathrm{BM}$, as specified in the simulation.

At $1 \mathrm{~mm}$, the solidified SS slag had $11.8 \mathrm{wt} \%$ glassy phase, corresponding to a temperature of $1090{ }^{\circ} \mathrm{C}$ in Fig. 6 . In samples obtained at higher points in the mould, the slag is completely crystalline, and the contents of RO first increased up to $33.8 \mathrm{wt} \%$ at $3 \mathrm{~mm}$ and then decreased to $21.5 \mathrm{wt} \%$ at $5 \mathrm{~mm}$. BM continuously increased up to $38.7 \mathrm{wt} \%$ at $5 \mathrm{~mm}$, and the lime content was $4.2 \mathrm{wt} \%$ at $5 \mathrm{~mm}$. These tendencies are identical to those presented in Fig. 6. The temperature in Fig. 6 is approximately $1050{ }^{\circ} \mathrm{C}$ for the sample at $3 \mathrm{~mm}$ and approximately $850{ }^{\circ} \mathrm{C}$ for the sample at $5 \mathrm{~mm}$. At all points, the simulated amount of larnite agrees well with the measured values, but the amounts of RO, BM and lime are slightly different than the values in Table 3. This difference may be due to nonequilibrium solidification conditions as $\mathrm{Ca}$ can be present in lime, BM and $\mathrm{RO}$ and $\mathrm{Fe}$ can be present in both $\mathrm{BM}$ and RO.

Figure 7 presents a micrograph obtained by SEM of the SS sample quenched in contact with the copper chilled plate. The dark grey phase is $\mathrm{Ca}_{2} \mathrm{SiO}_{4}\left(\beta-\mathrm{C}_{2} \mathrm{~S}\right)$-containing phosphorus, which was also observed by Gautier et al. [8]. The light grey phase is BM, and the brighter phase is RO. EDS analysis at different points revealed the crystalline phases, as indicated in Fig. 7, and the composition of the $\mathrm{RO}$ phase (Table 4) together with free $\mathrm{MgO}$ and $\mathrm{CaO}$, a limitation for the utilization of SS in cement. Qian et al. [6] reported that a lower $\mathrm{FeO} / \mathrm{MgO}$ ratio in the $\mathrm{RO}$ phase increase potential reactivity with water, affecting the expansion of the material. According to the results, the RO phase is a Mg-rich wustite that has the potential to react with water to produce brucite $\left(\mathrm{Mg}(\mathrm{OH})_{2}\right)$. 


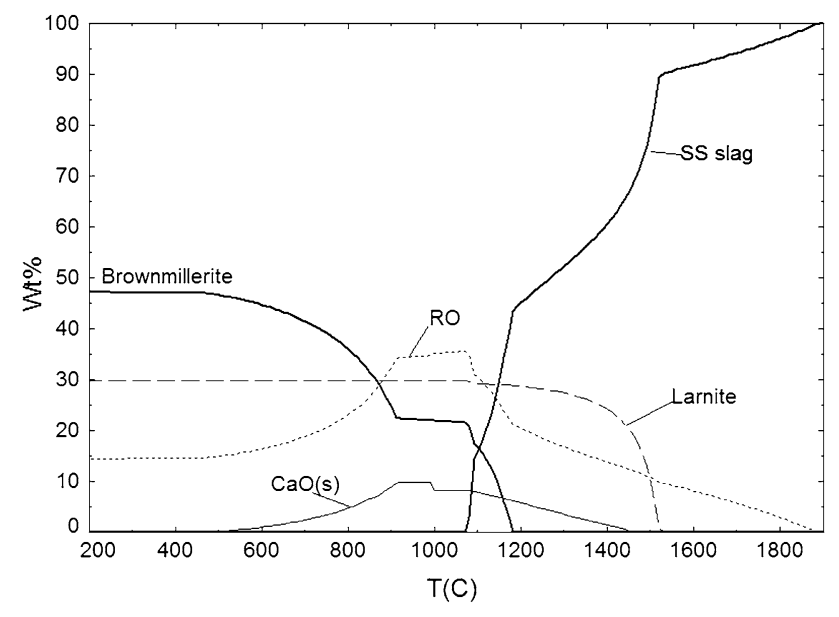

Fig. 6 Thermodynamic simulation of SS slag solidification performed in FactSage ${ }^{\mathrm{TM}}$ software

\section{SS-M1}

In the modified slag SS-M1, a higher content of glassy phase, approximately $25 \%$, that did not change with distance from the mould bottom was observed. The tendency towards glassy phase stabilization may be attributable to the lower basicity of modified slag [19], $B(\% \mathrm{CaO} /$ $\left.\% \mathrm{SiO}_{2}\right)=1.4$ compared to SS $(B=3.85)$.

Furthermore, a significant reduction of RO phase was observed that was caused in part by a decrease in iron oxides (total iron of $12 \mathrm{wt} \%$ ) due to the presence of modifying agents and in part by transfer of $\mathrm{MgO}$ from $\mathrm{RO}$ phase to merwinite. In addition to $\mathrm{MgO}$ stabilization as merwinite, the elimination of free lime from SS was observed.

The thermodynamic simulation of SS-M1 slag solidification (Fig. 8) revealed that the slag starts to solidify at $1610^{\circ} \mathrm{C}$ with the formation of the RO phase. Larnite forms at $1555^{\circ} \mathrm{C}$ and is completely transformed to merwinite at $1390{ }^{\circ} \mathrm{C}$. The formation of merwinite starts at $1430{ }^{\circ} \mathrm{C}$, and its content increases to nearly $70 \mathrm{wt} \%$. The last phase to form is melilite at $1260{ }^{\circ} \mathrm{C}$. These simulated results are in agreement with those in Table 3, with the exception that no melilite was detected in the XRD analysis and the measured amount of RO phase was lower than the simulated one. Because melilite was not formed, the elements are probably present in the merwinite phase $(\mathrm{Ca}, \mathrm{Mg}, \mathrm{Si}$ and $\mathrm{O}$ ), thus explaining the higher amount of this phase in the XRD results, and Al is in the glassy phase.

The microstructure of the SS-M1 slag presents crystalline phases regardless of the position of the sample, as shown in Fig. 9. EDS analysis revealed three main phases (merwinite, RO and glassy phase), as indicated in the figure and in agreement with the results presented in
Table 3. Table 5 presents the composition of the RO phase for the SS-M1 sample. In addition to the reduction of this phase compared to SS, the RO phase contained less $\mathrm{MgO}$ than that in SS, indicating the formation of $\mathrm{Mg}$ poor wustite and a reduced potential to react with water to form brucite and promote expansion, according to Qian et al. [6].

\section{SS-M2}

As shown in Table 1, the basicity and total iron content of slag SS-M2 were further reduced compared to slag SS-M1. The basicity was 1.1 , closer to the BF slag basicity (1.25). In addition, the alumina content increased to $11.5 \mathrm{wt} \%$. Due to this deeper modification, the glassy phase was stabilized, mainly in the region close to the chilled plate, where $91.2 \mathrm{wt} \%$ amorphous phase was detected (Table 3). This behaviour is similar to the BF slag. Moreover, high alumina contributes to a glassy structure [7]. In addition, the $\mathrm{RO}$ phase was eliminated and $\mathrm{MgO}$ was stabilized in phases with a lower $\mathrm{CaO} / \mathrm{SiO}_{2}$ ratio than merwinite $\left(3 \mathrm{CaO} \cdot \mathrm{MgO} \cdot 2 \mathrm{SiO}_{2}\right)$, such as monticellite $\left(\mathrm{CaO} \cdot \mathrm{MgO} \cdot \mathrm{SiO}_{2}\right)$ and akermanite $\left(2 \mathrm{CaO} \cdot \mathrm{MgO} \cdot 2 \mathrm{SiO}_{2}\right)$. Merwinite was dominant in slag SS-M1, which exhibited higher basicity. Furthermore, gehlenite $\left(2 \mathrm{CaO} \cdot \mathrm{Al}_{2} \mathrm{O}_{3} \cdot \mathrm{SiO}_{2}\right)$ was formed in slag SS-M2 because this slag has a high alumina content. This compound is also present in BF slag cooled slowly but formed a solid solution (melilite) with akermanite.

The thermodynamic simulated solidification of SS-M2 slag is presented in Fig. 10. The solidification starts at $1380{ }^{\circ} \mathrm{C}$ with the formation of merwinite, followed by the formation of melilite and $\mathrm{RO}$ at $1350{ }^{\circ} \mathrm{C}$ and the olivine phase at $1330{ }^{\circ} \mathrm{C}$. The XRD results at $2 \mathrm{~mm}$ (Table 3) revealed the presence of $91.2 \mathrm{wt} \%$ glassy phase, equivalent to the distribution of phases at $1350{ }^{\circ} \mathrm{C}$ in Fig. 10. At this point, the simulated amount of merwinite was approximately $10 \mathrm{wt} \%$, higher than that measured by XRD. The akermanite present in the $2 \mathrm{~mm}$ sample is simulated in the melilite phase. In the sample at $6 \mathrm{~mm}$, monticellite that is simulated as olivine phase and akermanite and gehlenite that are simulated as melilite are present. Therefore, the simulated amount of olivine can be compared to the summed amounts of monticellite and merwinite in Table 3 and the simulated amount of melilite to the amounts of akermanite and gehlenite. This comparison corresponds to $1250{ }^{\circ} \mathrm{C}$, which is the solidus temperature. At this temperature, the amount of melilite is approximately $65 \mathrm{wt} \%$, and the amount of olivine is approximately $35 \mathrm{wt} \%$, which is also the phase distribution for the samples taken at 6 and $30 \mathrm{~mm}$.

The microstructure of SS-M2 slag is shown in Fig. 11. A continuous structure without crystals was observed in the region of the interface with the copper plate, up to $2.7 \mathrm{~mm}$ 
(a)

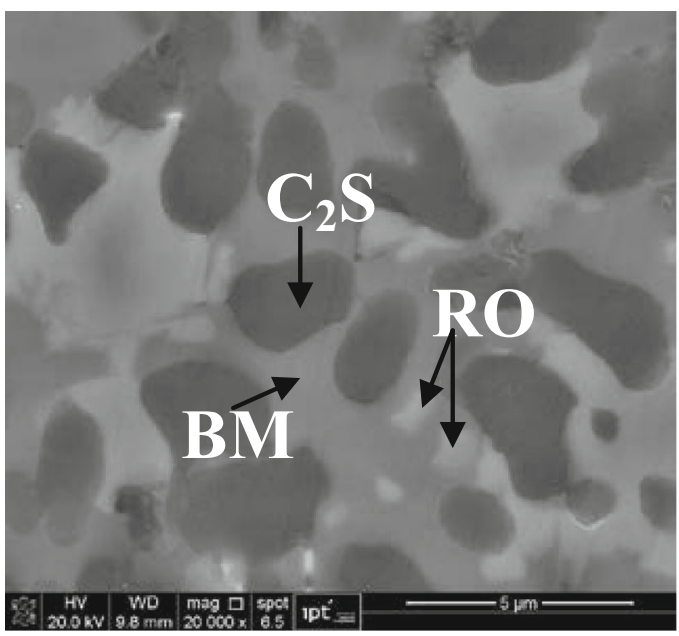

(c)

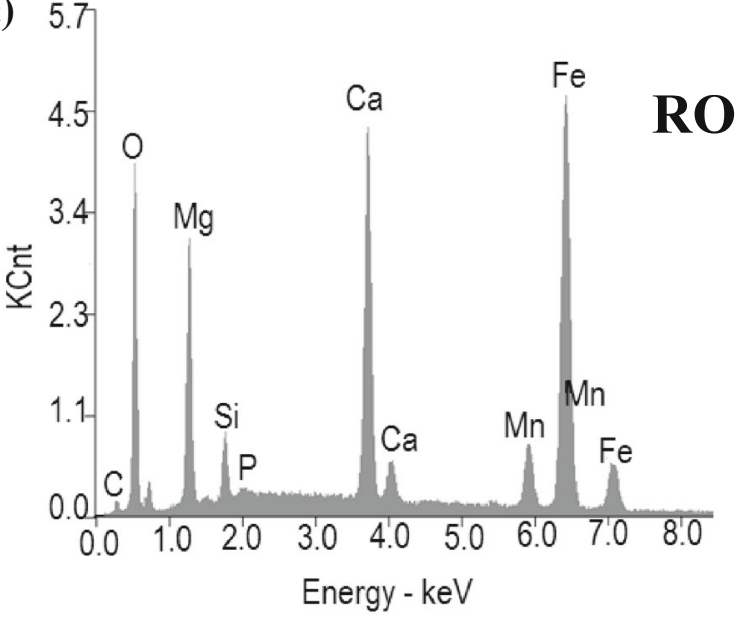

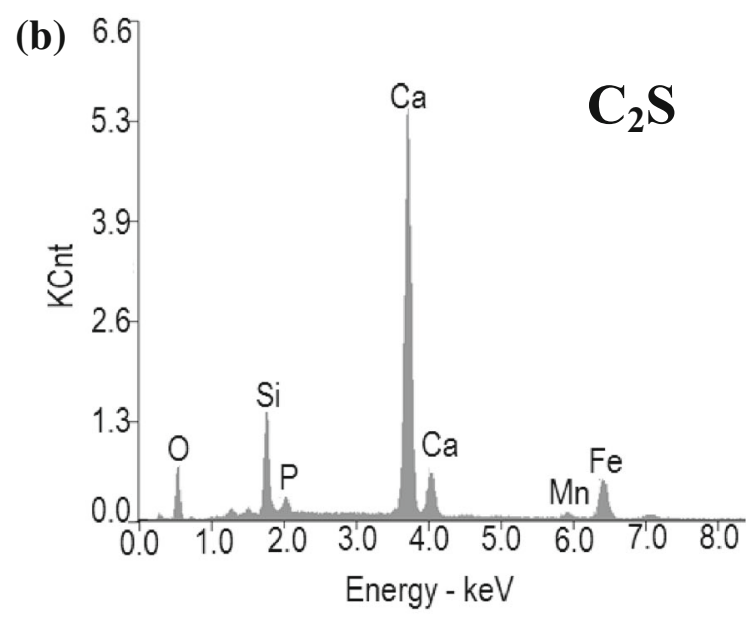

(d) 4.6

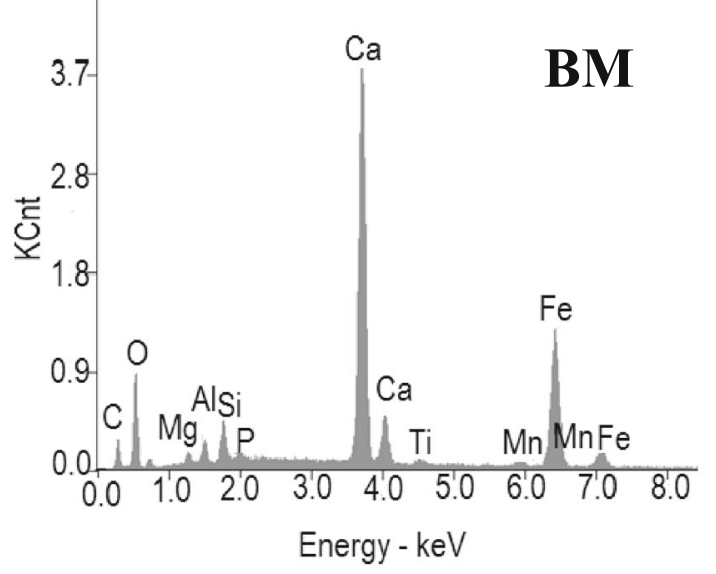

Fig. 7 a Micrograph by scanning electron microscopy (secondary electron image) of the sample SS located at $1 \mathrm{~mm}$ from interface between the slag and the $\mathrm{Cu}$ chilled plate and $\mathbf{b}-\mathbf{d}$ EDS spectra of the phases indicated in the figure

Table 4 Chemical composition (mol\%) of RO phase determined by EDS analysis for the sample SS

\begin{tabular}{lllll}
\hline Components & $\mathrm{CaO}$ & $\mathrm{MgO}$ & $\mathrm{FeO}$ & $\mathrm{MnO}$ \\
\hline $\mathrm{mol} \%$ & 5.1 & 44.9 & 41.9 & 8.2 \\
\hline
\end{tabular}

(Fig. 11a). Far from this region, only the crystalline phase was detected. At $15 \mathrm{~mm}$, different phases were observed. Phase 2 was composed of $\mathrm{Ca}, \mathrm{Si}, \mathrm{Mg}$ and $\mathrm{O}$, which are elements present in the merwinite, monticellite and akermanite phases, whereas phase 3 was composed of $\mathrm{Ca}, \mathrm{Mg}$, $\mathrm{Al}$ and $\mathrm{O}$, which are elements present in melilite. This analysis indicates that the akermanite and gehlenite detected as separated by XRD (Table 3) could be together, as predicted by the simulation presented in Fig. 10.

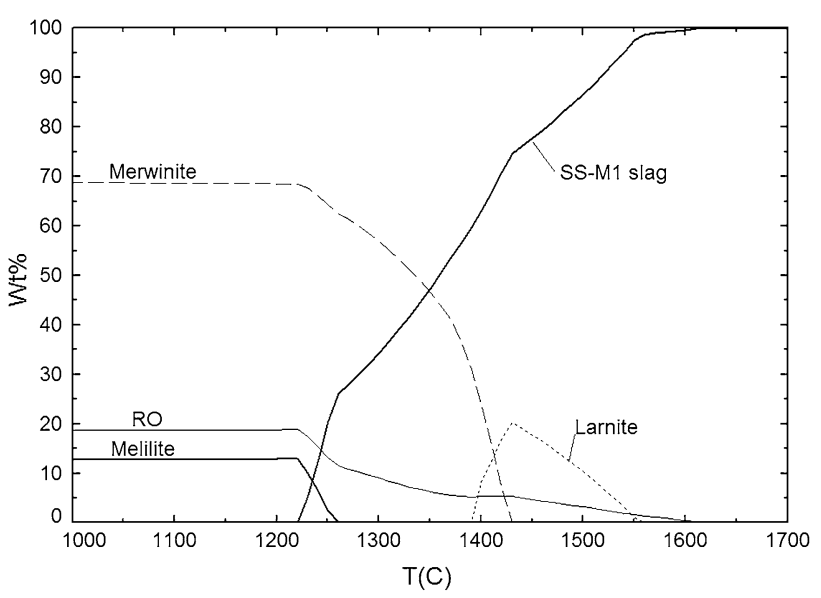

Fig. 8 Thermodynamic simulation of SS-M1 slag solidification performed in FactSage ${ }^{\mathrm{TM}}$ software 

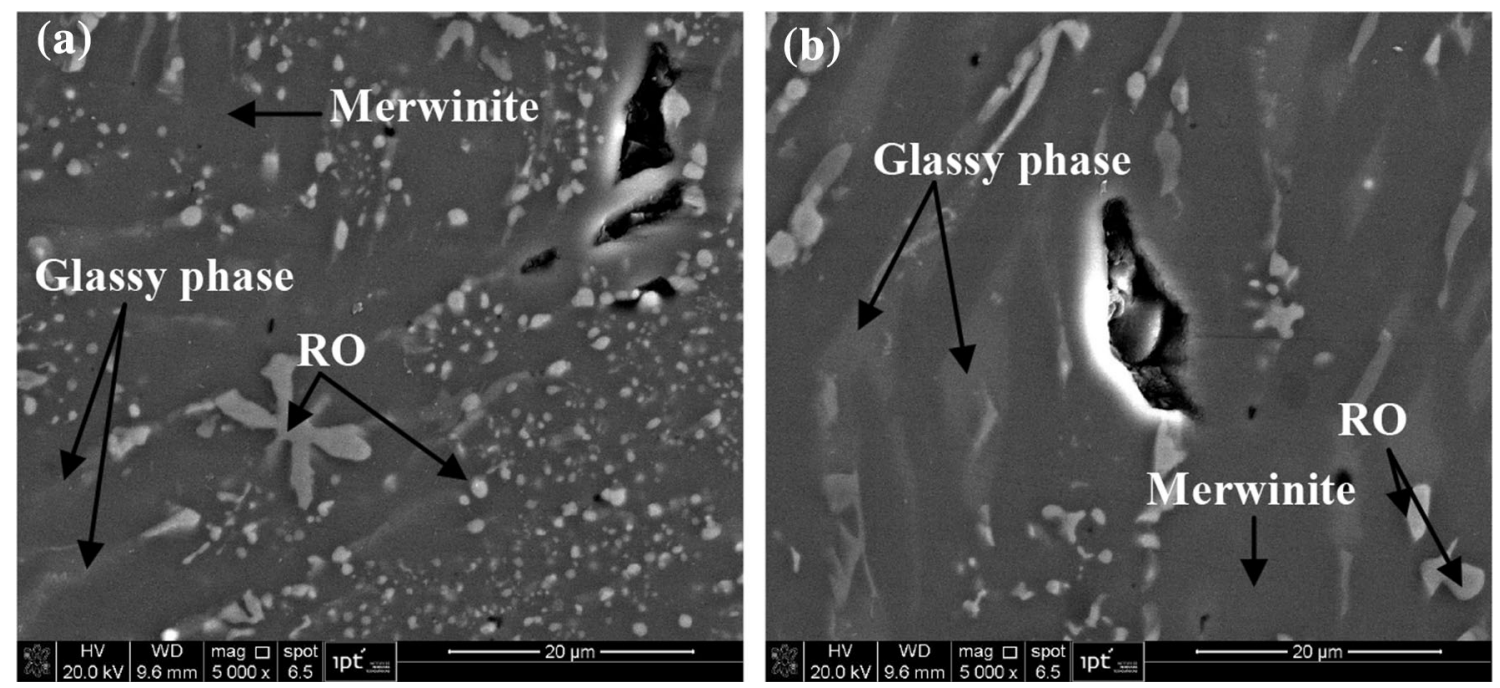

Fig. 9 a Micrograph by scanning electron microscopy (secondary electron image) of the sample SS-M1 quenched in contact with Cu chilled plate and $\mathbf{b} 5 \mathrm{~mm}$ from the interface with the $\mathrm{Cu}$ chilled plate

Table 5 Chemical composition $(\mathrm{mol} \%)$ of RO phase determined by EDS analysis for the sample SS-M1

\begin{tabular}{lllll}
\hline Components & $\mathrm{CaO}$ & $\mathrm{MgO}$ & $\mathrm{FeO}$ & $\mathrm{MnO}$ \\
\hline $\mathrm{mol} \%$ & 1.9 & 22.4 & 67.2 & 15.4 \\
\hline
\end{tabular}

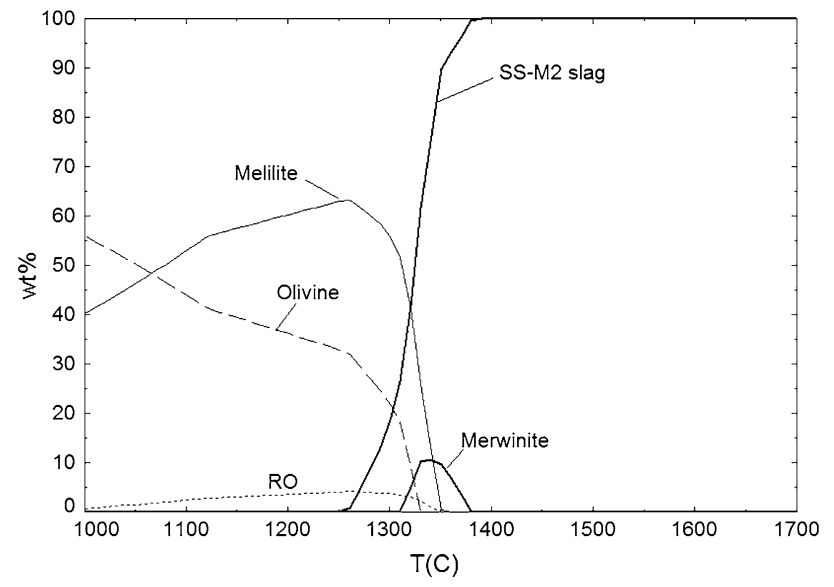

Fig. 10 Thermodynamic simulation of SS-M2 slag solidification performed in FactSage ${ }^{\mathrm{TM}}$ software

\section{SS-M3}

The modified slag SS-M3 is a reproduction of slag SS-M1 at a larger scale $(300 \mathrm{~kg})$. Two samples of this slag (SSM3) were obtained; one sample was naturally cooled in the same reactor where the modification process occurred (SSM3a), and the other sample was cooled by steel balls (SSM3b). As shown in Table 3, small differences in the glassy phase content were observed for natural cooling or cooling promoted by steel balls. This small difference indicates that the relationship between steel/slag and cooling conditions requires further adjustment.

No significant differences in the RO phase were observed in slags SS-M1 and SS-M3; both exhibited a considerable reduction of the RO phase compared to the SS without any modification. $\mathrm{MgO}$ was stabilized in crystalline phases such as merwinite, akermanite and monticellite. In addition, the amount of glassy phase was similar to that in slag SS-M1 (Table 3) and was unaffected by cooling conditions. Table 6 presents the chemical composition of the RO phase determined by EDS analysis. In both SS-M1 and SS-M3, RO contained more than $53 \mathrm{~mol} \% \mathrm{FeO}$ and less than $32 \mathrm{~mol} \% \mathrm{MgO}$, resulting in a $\mathrm{RO}$ phase richer in $\mathrm{FeO}$ than $\mathrm{MgO}$.

The thermodynamic simulation of SS-M3 slag solidification performed using FactSage ${ }^{\mathrm{TM}}$ software is identical to that presented in Fig. 8 for SS-M1 because the chemical compositions of the two slags are similar (Table 1).

\section{SS-M4}

The slag SS-M4 was modified with the aim of achieving lower basicity $\left(\mathrm{CaO} / \mathrm{SiO}_{2}=1.16\right)$ than slag SS-M3 $(\mathrm{CaO} /$ $\mathrm{SiO}_{2}=1.37$ ) and further decreasing iron oxides. In contrast to slag SS-M3, an effect of cooling conditions on glassy phase formation was observed in slag SS-M4, with $62.8 \mathrm{wt} \%$ glassy phase under water quenching (SS-M4c), $11.5 \mathrm{wt} \%$ by steel ball cooling (SS-M4b) and no glassy phase under natural cooling (SS-M4a). As observed in slag $\mathrm{SS}-\mathrm{M} 3, \mathrm{MgO}$ was stabilized as monticellite, akermanite and merwinite. The simulation conducted in FactSage ${ }^{\mathrm{TM}}$ (Fig. 12) is consistent with the experimental results. The 
(a)

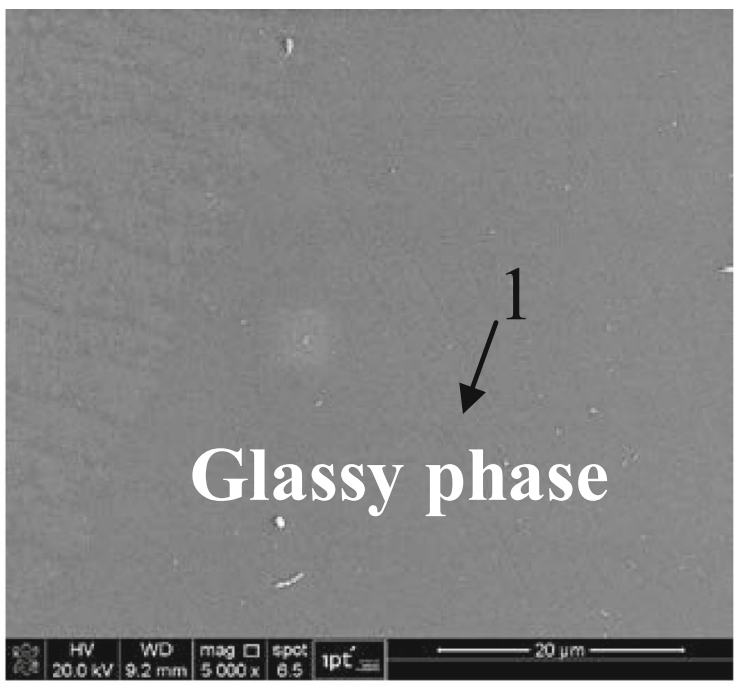

(c)

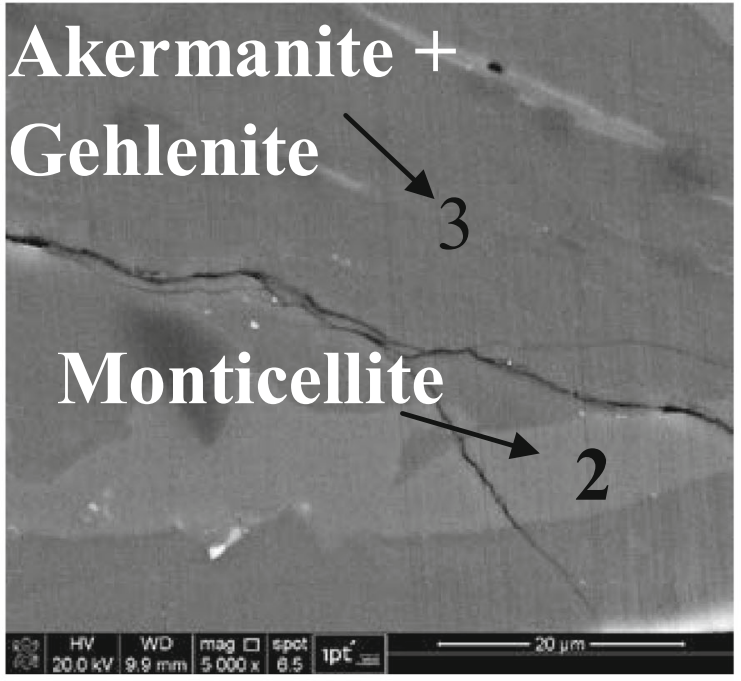

(b) 6.5

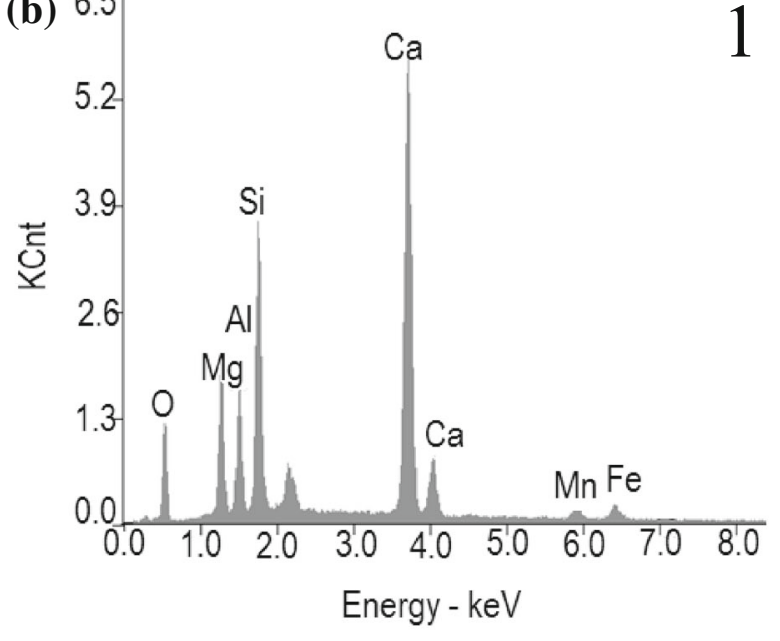

(d) 7.9

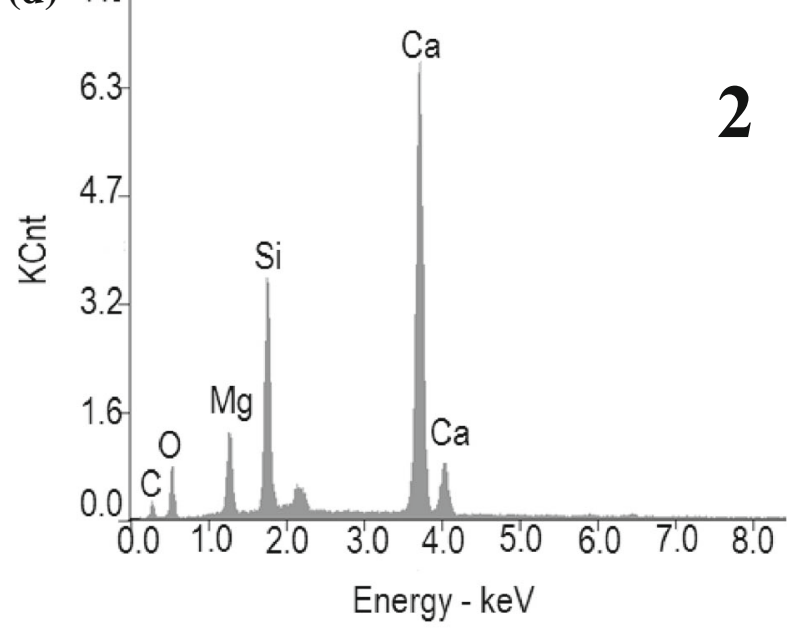

(e) 4.1

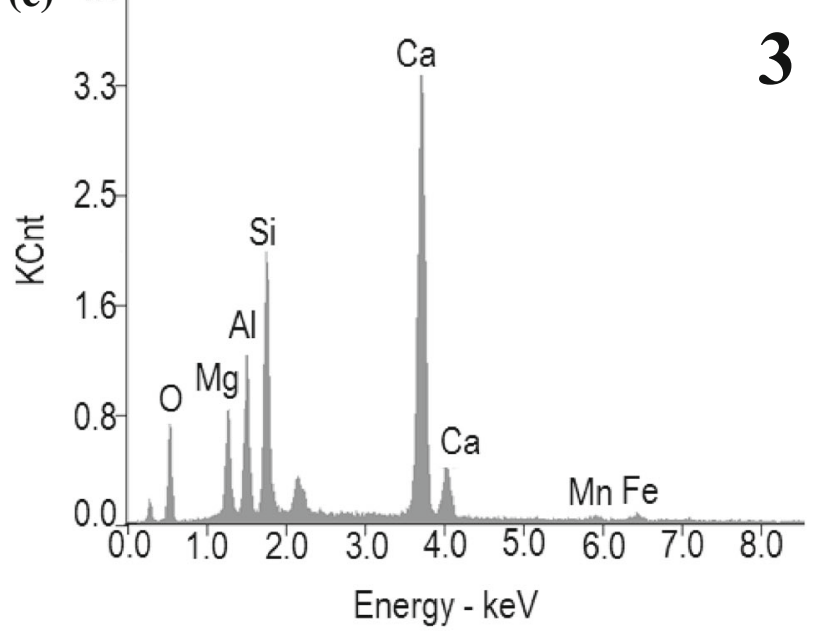

Fig. 11 Micrographs by scanning electron microscopy (secondary electron image) of solidified SS-M2 slag at different heights from copper chilled plate: a $2.7 \mathrm{~mm}$, c $15 \mathrm{~mm}$, b-e EDS spectra from the points indicated in the figures 
Table 6 Chemical composition of RO (mol\%) phase determined by EDS analysis for the sample SS-M3

\begin{tabular}{lllll}
\hline Components & $\mathrm{CaO}$ & $\mathrm{MgO}$ & $\mathrm{FeO}$ & $\mathrm{MnO}$ \\
\hline $\mathrm{mol} \%$ & 3.7 & 31.9 & 53.3 & 11.1 \\
\hline
\end{tabular}

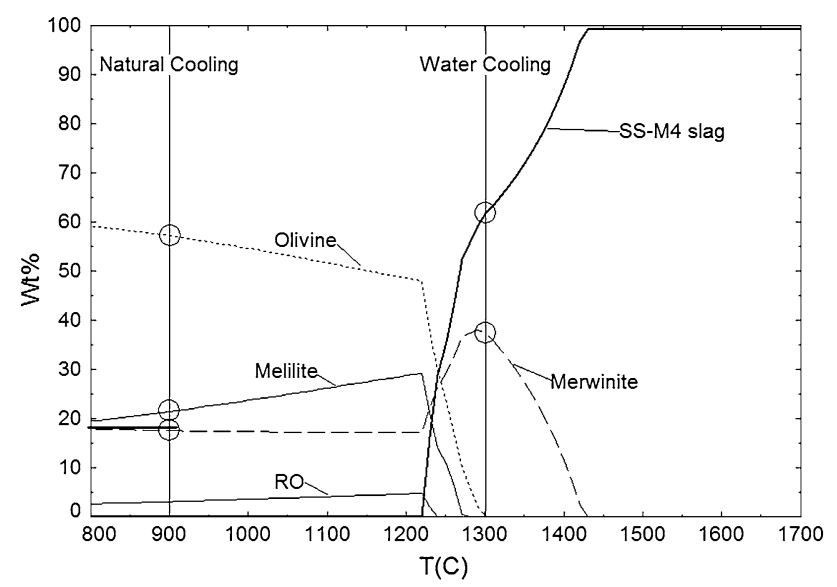

Fig. 12 Thermodynamic simulation of SS-M4 slag solidification performed in FactSage ${ }^{\mathrm{TM}}$ software

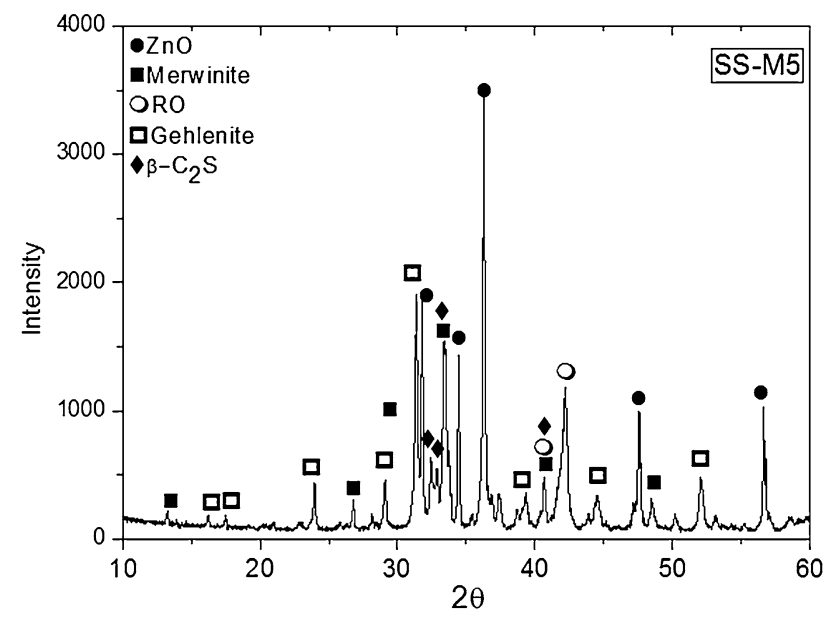

Fig. 13 XRD pattern of SS-M5. ZnO was used as internal pattern to quantify glassy phase using Rietveld method

water-cooled sample corresponds to a temperature of $1300{ }^{\circ} \mathrm{C}$, which results in approximately $65 \mathrm{wt} \%$ glassy phase and $35 \mathrm{wt} \%$ merwinite. The naturally cooled sample corresponds to a temperature of $910{ }^{\circ} \mathrm{C}$ with approximately $60 \mathrm{wt} \%$ monticellite, $20 \mathrm{wt} \%$ melilite (akermanite + gehlenite) and $18 \mathrm{wt} \%$ merwinite.

\section{SS-M5}

The slag SS-M5, which was modified with the purpose of increasing the $\mathrm{Al}_{2} \mathrm{O}_{3}$ content, exhibited $16.5 \mathrm{wt} \% \mathrm{RO}$
Table 7 Chemical composition ( $\mathrm{mol} \%$ ) of RO phase determined by EDS analysis for the sample SS-M5

\begin{tabular}{lllll}
\hline Components & $\mathrm{CaO}$ & $\mathrm{MgO}$ & $\mathrm{FeO}$ & $\mathrm{MnO}$ \\
\hline $\mathrm{mol} \%$ & 0.0 & 34.1 & 53.0 & 12.0 \\
\hline
\end{tabular}

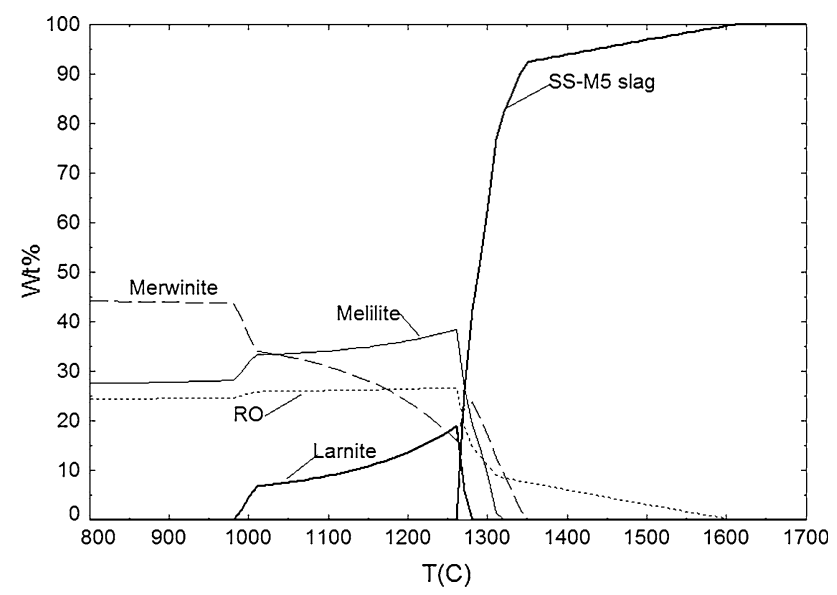

Fig. 14 Thermodynamic simulation of SS-M5 slag solidification performed in FactSage ${ }^{\mathrm{TM}}$ software

phase, a high content that those observed in slags SS-M3 and SS-M4. However, a higher amount of larnite was observed compared to previous slags. In addition, this slag exhibited $\mathrm{MgO}$ stabilized as merwinite as well as gehlenite, which must contain most of the alumina in the slag. Figure 13 shows the XRD pattern of SS-M5 sample. As shown in Table 7, the chemical composition ( $\mathrm{mol} \%$ ) of the RO phase determined by EDS analysis for sample SS-M5 was similar to that for SS-M3, except for the absence of $\mathrm{CaO}$.

The thermodynamic simulated solidification of SS-M5 slag is presented in Fig. 14. The solidification starts at $1600{ }^{\circ} \mathrm{C}$ with the formation of RO, merwinite at $1350{ }^{\circ} \mathrm{C}$, melilite at $1310{ }^{\circ} \mathrm{C}$ and larnite at $1280{ }^{\circ} \mathrm{C}$. All these phases were detected by XRD analysis, except melilite, which was identified only in the thermodynamic simulation. However, melilite contains $\mathrm{Al}$, as does gehlenite, which was detected by XRD.

\section{Cement Characterization and Properties}

Table 8 presents the compressive strength, volume soundness, autoclave expansion and total hydration heat $(72 \mathrm{~h})$ for cements PSC-SS-M4, PSC-SS-M5, OPC, PSC-BFS and PSC-SS.

The compressive strength at ages of 3, 7 and 28 days was $28.3 ; 31.3$ and $36.9 \mathrm{MPa}$, respectively, for PSC-SSM4, corresponding to Class 32, and 29.9, 37.7 and 41.0 MPa for PSC-SS-M5, corresponding to Class 40, 
Table 8 Compressive strength, volume soundness, autoclave expansion and accumulated hydration heat (72 h) for cements OPC, PSC-BFS, PSC-SS, PSC-SS-M4 and PSC-SS-M5

\begin{tabular}{|c|c|c|c|c|c|c|c|}
\hline \multirow[t]{2}{*}{ Slags } & \multicolumn{3}{|c|}{ Compressive strength (MPa) } & \multicolumn{2}{|c|}{ Soundness (mm) } & \multirow{2}{*}{$\begin{array}{l}\text { Autoclave } \\
\text { expansion } \\
(\%)\end{array}$} & \multirow{2}{*}{$\begin{array}{l}\text { Total hydration } \\
\text { heat }\left(\mathrm{J} \mathrm{g}^{-1}\right) \\
\text { PSC's (3d) }\end{array}$} \\
\hline & $3 d$ & $7 d$ & 28 & Cold & Hot & & \\
\hline $\mathrm{OPC}$ & 39.6 & 43.2 & 52.7 & 0.5 & 0.0 & 0.03 & 339.4 \\
\hline$P S C-B F S_{\text {in natura }}$ & 30.9 & 41.4 & 52.6 & 0.5 & 0.0 & 0.01 & 301.1 \\
\hline $\mathrm{PSC} \mathrm{SS}_{\text {in natura }}$ & 27.0 & 34.7 & 41.1 & 0.5 & 1.0 & 0.44 & 280.5 \\
\hline PSC-SS-M4 & 28.3 & 31.2 & 36.9 & 0.5 & 0.0 & 0.04 & 278.2 \\
\hline PSC-SS-M5 & 29.9 & 37.7 & 41.0 & 0.0 & 0.0 & 0.07 & 314.1 \\
\hline Experimental maximum standard deviation & 3.7 & 3.0 & 2.2 & $0.5[20]$ & $0.5[20]$ & $0.01[21]$ & $4.3[22]$ \\
\hline \multicolumn{8}{|l|}{ NBR 11578} \\
\hline Class 25 & $\geq 8.0$ & $\geq 15.0$ & $\geq 25.0$ & $\leq 5$ & $\leq 5$ & - & - \\
\hline Class 32 & $\geq 10.0$ & $\geq 20.0$ & $\geq 32.0$ & $\leq 5$ & $\leq 5$ & - & - \\
\hline Class 40 & $\geq 15.0$ & $\geq 25.0$ & $\geq 40.0$ & $\leq 5$ & $\leq 5$ & - & - \\
\hline ASTM C 150 & - & - & - & - & - & $\leq 0.80$ & - \\
\hline
\end{tabular}

according to standard NBR 11578 (similar to EN 197-1). Although there was no significant increase in compressive strength in the early ages (3, 7 and 28 days), the presence of $\beta-\mathrm{C}_{2} \mathrm{~S}$ suggests the potential for a gain in compressive strength at later ages. Besides the evaluation at ages later than 28 days, additional tests are being carried out with the aim of increasing reactive phases to evaluate their effects on the compressive strengths. In addition, tests comparing cement blended with slag and silica filler cement will be performed to evaluate the real contribution of modified slags to the cement.

The stabilization of PSC-SS-M4 was confirmed by the volume soundness test (ISO EN 196-3), which did not indicate any volume variation in cold or hot water. Furthermore, in the autoclave test (ASTM C 151), the same mixture resulted in an expansion approximately 10 times smaller $(0.04 \%)$ than that determined in a PSC-SS sample produced with steel slag without any modification (PSCSS) (Table 8).

PSC-SS-M5, when used as cement admixture in a proportion of $25 \mathrm{wt} \%$ slag and $75 \mathrm{wt} \%$ OPC, did not exhibit expansion in the cold or hot water test (volume soundness test) and also exhibited low volume soundness $(0.07 \%)$ in the autoclave test, confirming appropriate stabilization.

For the cumulative heat in the first 3 days (72 h), PSCSS-M5 exhibited a value of $314.1 \mathrm{~J} / \mathrm{g}$, lower than OPC cement $(339.4 \mathrm{~J} / \mathrm{g}$ ) but higher than PSC-SS-M4 $(278.2 \mathrm{~J} / \mathrm{g}$ ) and PSC-BFS $(301.1 \mathrm{~J} / \mathrm{g})$. Although slag SS-M5 contains more $\beta-\mathrm{C}_{2} \mathrm{~S}(12.1 \mathrm{wt} \%)$, a reactive phase in Portland cement, than SS-M4 (approximately $5 \mathrm{wt} \%$ ), $\beta-\mathrm{C}_{2} \mathrm{~S}$ is reactive only in later ages. Therefore, further study is needed to determine if others phases in slag SS-M5 could contribute to reactivity in early ages. In addition, analysis of free $\mathrm{CaO}$ (Table 3) revealed that sample SS-M5 contained only $0.13 \mathrm{wt} \% \mathrm{CaO}$, insufficient to justify the observed heat release.

Expansion was not significant $(<0.07 \%)$ because the RO phase for SS-M5 is a Mg-poor wustite (Table 7), which exhibits low expansion according to Qian et al. [6]. These results demonstrate that modified slag can be used to produce PSC.

Further experiments are underway to optimize parameters such as basicity, alumina content and cooling conditions. The preliminary results indicate potential to achieve a higher amorphous phase or reactive crystalline phase content.

\section{Conclusions}

The main conclusions can be summarized as follows:

1. Only under cooling rates higher than $4{ }^{\circ} \mathrm{C} / \mathrm{s}$ was it possible to achieve more than $95 \mathrm{wt} \%$ glassy phase in BF slag.

2. The crystalline fraction of BF slag exhibited phases such as akermanite, merwinite and melilite, which are typically found in BF slags cooled under slow rates.

3. The SS was mostly crystalline, even under fast cooling, with phases typically found in this type of slag: brownmillerite, larnite, RO phase and lime. The SS also exhibited an increase in brownmillerite under slower cooling because calcium ferrite or brownmillerite is one of the last phases to crystallize.

4. Higher silica and alumina and lower iron oxides in modified slags contributed to glassy phase formation under fast cooling. Furthermore, the amount of RO phase decreased due the decrease in iron oxides and 
$\mathrm{MgO}$ stabilization in calcium and magnesium silicates (merwinite, monticellite and arkemanite).

5. The $\mathrm{MgO} / \mathrm{FeO}$ ratio of the $\mathrm{RO}$ phase was lower in modified slags than in SS slag, decreasing the possible expansion effect of the RO phase.

6. The modification of SS decreased its basicity from 3.8 to 1.4 and reduced the total iron content from approximately $32 \mathrm{wt} \%$ to approximately $12 \mathrm{wt} \%$, thus increasing the amount of glassy phase in the slag from $11.8 \mathrm{wt} \%$ to approximately $25 \mathrm{wt} \%$. In addition, the change in basicity to 1.1 , total iron to $3 \mathrm{wt} \%$ and alumina to $11.5 \mathrm{wt} \%$ resulted in an amorphous phase of $91.2 \mathrm{wt} \%$ in the slag under a high cooling rate.

7. Although the modification process did not result in a strong increase in slag reactivity, stabilization of the modified slags was confirmed by the volume soundness test in cold and hot water, which did not indicate any expansion, and by the low expansion (0.04 and $0.07 \%$ ) observed in the autoclave test (ASTM C 151) conducted using cement samples produced from a mixture of $75 \mathrm{wt} \%$ ordinary cement and $25 \mathrm{wt} \%$ modified slag.

8. The cement produced with the mixture containing SSM5 slag generated an accumulated heat of $314 \mathrm{~J} / \mathrm{g}$ in $72 \mathrm{~h}$, whereas the same mixture based on BF slag resulted in $301.1 \mathrm{~J} / \mathrm{g}$. The compressive strength at 3, 7 and 28 days was 29.9, 37.7 and $41.0 \mathrm{MPa}$, respectively, higher than the minimum specified at the same ages according to standard NBR 11578. Although the contribution of modified slags to compressive strength was not significant up 28 days, its contribution may increase at later ages due to later hydration of some minerals. Additional test at older ages are needed to evaluate this possibility.

Acknowledgments The authors acknowledge financial support from InterCement and Embrapii.

\section{References}

1. Belhadj E, Diliberto C, Lecomte A (2012) Characterization and activation of basic oxygen furnace slag. Cement Concrete Comp 34:34-40. doi:10.1016/j.cemconcomp.2011.08.012

2. Faraone N, Tonello G, Furlani E, Maschio S (2009) Steelmaking slag as aggregate for mortars: effects of particle dimension on compression strength. Chemosphere 77:1152-1156. doi:10.1016/ j.chemosphere.2009.08.002

3. Li JX, Yu QJ, Wei JX, Zhang TS (2011) Structural characteristics and hydration kinetics of modified steel slag. Cement Concrete Res 41:324-329. doi:10.1016/j.cemconres.2010.11.018

4. Tossavainen M, Engstrom F, Yang Q, Menad N, Larsson ML, Bjorkman B (2007) Characteristic of steel slag under different cooling conditions. Waste Manage 27:1335-1344. doi:10.1016/j. wasman.2006.08.002

5. Kriskova L, Pontikes Y, Pandelaers L, Cizer O, Jones PT, van Balen K, Blanpain B (2013) Effect of high cooling rates on the mineralogy and hydraulic properties of stainless steel slags. Metall Mater Trans B 44:1173-1184. doi:10.1007/s11663-0139894-9

6. Qian GR, Sun DD, Tay JH, Lai ZY (2002) Hydrothermal reaction and autoclave stability of $\mathrm{Mg}$ bearing RO phase in steel slag. Brit Ceram T 101(4):159-164. doi:10.1179/096797802225003415

7. Mostafa NY, El-Hemaly SAS, Al-Wakeel EI, El-Korashy SA, Brown PW (2001) Characterization and evaluation of the hydraulic activity of water-cooled slag and air-cooled slag. Cement Concrete Res 31:899-904. doi:10.1016/S0008-8846(01)00497-5

8. Gautier M, Poirier J, Bodenan F, Franceschini G, Véron E (2013) Basic oxygen furnace (BOF) slag cooling: laboratory characteristics and prediction calculations. Int $\mathrm{J}$ Miner Process 123:94-101. doi:10.1016/j.minpro.2013.05.002

9. Mills KC, Yuan L, Jones RT (2011) Estimating the physical properties of slags. J S Afr Inst Min Metall 111:649-658

10. Ferreira Neto JB, Ribeiro TR, Lotto AA, Quarcioni VA, Chotoli FF (2014) Sistema de modificação de escória, Patent application BR 10023505 1, pp 1-12

11. Solvi M, Greiveldinger B, Hoffmann M, Friederici C, Michels D (2012) Granulation of metallurgical slag. WO2012/0836 A1, pp $1-15$

12. Kappes H, Michels D (2015) Dry slag granulation and energy recovery. In: Proceedings of the fourth international slag valorisation symposium. Leuven, pp 39-52

13. Xu Z, Hwang J, Greenlund R, Huang X, Luo J, Anschuetz S (2003) Quantitative determination of metallic iron content in steel-making slag. J Miner Mater Charact Eng 2:65-70. doi: 10. 4236/jmmce.2003.21006

14. Fredericci C, Zanotto ED, Ziemath EC (2000) Crystallization mechanism and properties of a blast furnace slag glass. J Non-Cryst Solids 273(1-3):64-75. doi:10.1016/S0022-3093(00)00145-9

15. Kashiwaya Y, Nakauchi T, Pham KS, Akiyama S, Ishii K (2007) Crystallization behaviors concerned with TTT and CCT diagrams of blast furnace slag using hot thermocouple technique. ISIJ Int 47(1):44-52. doi:10.2355/isijinternational.47.44

16. Gan L, Zhang CX, Shangguan FQ, Li XP (2012) A differential scanning calorimetry method for construction of continuous cooling transformation diagram of blast furnace slag. Metall Mater Trans B 43:460-467. doi:10.1007/s11663-011-9631-1

17. Jung SS, Sohn II (2013) Effect of $\mathrm{FeO}$ concentration on the crystallization of high-temperature $\mathrm{CaO}-\mathrm{Al}_{2} \mathrm{O}_{3}-\mathrm{MgO}-\mathrm{FeO}$ melts. J Am Ceram Soc 96(4):1309-1316. doi:10.1111/jace.12134

18. Shi CJ (2004) Steel slag-its production, processing, characteristics and cementitious properties. J Mater Civil Eng 16:230-236. doi:10.1061/(ASCE)0899-1561(2004)16:3(230)

19. Ryu HG, Zhang ZT, Cho JW, Wen GH, Sridhar S (2010) Crystallization behaviors of slags through a heat flux simulator. ISIJ Int 50(8):1142-1150. doi:10.2355/isijinternational.50.1142

20. Associação Brasileira de Normas Técnicas (ABNT) NBR 11582 (1991) Cimento Portland-determinação da expansibilidade de Le Chatelier, pp 1-2

21. American Society for Testing Materials (ASTM) C 151 (2005) Autoclave expansion of hydraulic cement, pp 1-4

22. Chotoli F, Martho ACR, Quarcioni VA, Castanho MA (2013) Avaliação do perfil térmico de calorímetro de condução isotérmico para estudos de calor de hidratação de pastas de cimento Portland. Enqualab-Congresso de Qualidade em Metrologia, pp 1-6 